\title{
O MURO ISRAELENSE. REFLEXÕES E PERSPECTIVAS JURÍDICAS (VISÃO MULTICULTURAL)
}

\author{
Hidemberg ALVES DA FROTA*
}

RESUMEN: Este artículo estudia la legalidad del muro israelí en el territorio palestino ocupado; examina las opiniones legales de juristas árabes, juristas judíos y juristas internacionalistas, y dibuja las perspectivas legales para el futuro.

ABSTRACT: This article studies the legality of the Israeli wall in the Occupied Palestinian Territory; examines legal opinions from Arab, Jewish and internationalist jurists, and draws legal perspectives for the future.

RÉSUMÉ: Cet article étudie la légalité du mur Israelien dans le Territoire palestinien Occupé; examine des opinions légales des juristes árabes, des juristes juifs et des juristes internationalistes. Dessine des perspectives légales pour l'avenir.

* Advogado. Bacharel em Direito pelo Centro Universitário de Ensino Superior do Amazonas. Associado do Instituto Brasileiro de Ciências Criminais. 
Agora mais do que nunca, nós precisamos substituir noções estereotipadas e simplistas sobre o Oriente Médio por entendimento objetivo detalhado**

Embaixador Edward S. Walker, Jr., presidente do Instituto do Oriente Médio (EUA).

SumÁrio: I. Introdução. II. Antecedentes histórico-jurídicos. III. Os fundamentos jurídicos da Opinião Consultiva da CIJ de 9 de julho de 2004. IV. Os pronunciamentos judiciais anexos à Opinião Consultiva da CIJ de 9 de julho de 2004. V. O contraponto israelita. VI. A resposta palestina às argumentações israelitas. VII. A proposta de Estado único. VIII. Considerações críticas. IX. Conclusão. X. Bibliografia.

\section{INTRODUÇÃO}

A Corte Internacional de Justiça, em resposta à Assembléia-Geral das Nações Unidas, alinhavou opinião consultiva (advisory opinion) em 9 de julho de 2004, ${ }^{1}$ que considerou, por ampla maioria (quase à unanimidade, 14 votos a 1), ${ }^{2}$ contrária ao Direito Internacional a construção, pelo Governo israelense, do que se convencionou ser nominado muro defensivo, cerca separatória ou, ainda, barreira de segurança, erigida no Território Palestino Ocupado, área sob jugo do Estado de Israel em conseqüência da Guerra dos Seis Dias (5 a 10 de junho de 1967).

$\mathrm{Na}$ ótica da Corte Internacional de Justiça, não assiste a Israel o direito de levantar tal edificação, porque não situada em território israelense e sim palestino. Afinal, o Conselho de Segurança da ONU, de modo

* "Now more than ever, we must replace stereotyped and simplistic notions about the Middle East with detailed objetive undestanding". Lema do Instituto do Oriente Médio (Middle East Institute, Washington, DC, EUA). Disponível em: http://www.mideasti.org. Acesso em: 22 ago. 2005, tradução livre nossa.

1 Organização das Nações Unidas, International Court of Justice. Advisory Opinion, Legal consequences of the construction of a wall in the Occupied Palestinian Territory, The Hague, 9 de julio de 2004. Disponível em: http://www.icj-cij.org. Acesso em: 22 de agosto de 2005.

2 Posicionamento majoritário adotado pelo presidente Shi, pelo vice-presidente Ranjeva, acompanhado pelos também juízes Guillaume, Koroma, Vereshchetin, Higgins, Parra-Aranguren, Kooijmans, Rezek, Al-Khasawneh, Elaraby, Owada, Simma e Tomka, do qual dissentiu o juiz Buergenthal. 
unânime, por intermédio da Resolução no. 242, de 22 de novembro de 1967, declarara ilegal a anexação por Israel, durante a Guerra dos Seis Dias, de regiões limítrofes de maioria árabe: Faixa de Gaza, Península do Sinai, Cisjordânia (inclusive Jerusalém Oriental) e Colinas do Golã.

O Direito Internacional - frisou a CIJ- proíbe a aquisição de territórios por meio da guerra, ${ }^{3}$ inclusive anexações fomentadas pela criação de fatos consumados.

No Território Palestino Ocupado, a barreira de segurança, à primeira vista, propiciaria separação de grande parte da minoria judaica da maioria palestina lá localizadas. Além disso, robusteceria a segurança do Estado de Israel. Na visão da CIJ, contudo, o muro defensivo israelense serve não apenas para proteger o Estado de Israel e os colonos judaicos do terrorismo palestino, como também para consolidar seja a presença israelita naquelas plagas, seja as fronteiras (expandidas) do Estado de Israel, em face do possível futuro Estado da Palestina, a fim de que, quando este surgir, as colônias judaicas representem fato consumado, a legitimar, aos olhos do Direito Internacional, a anexação do espaço palestino ocupado por elas.

$\mathrm{O}$ isolamento acarretado pelo advento do muro defensivo atingiria o âmago da dignidade das comunidades palestinas intramuros, tolhidas do exercício de ampla gama de direitos relacionada à autodeterminação, à sobrevivência e à vida digna, à integridade pessoal e coletiva, ao desenvolvimento social e econômico.

Consoante percebeu a CIJ, por meio da barreira de segurança israelense, vulneraram-se, inclusive, a liberdade da população palestina se movimentar, escolher a moradia onde residir e visitar locais sagrados, assim como a incolumidade do lar, da honra, da esfera privada e familiar e o direito de propriedade, ao trabalho e à saúde dos habitantes palestinos.

A seguir, este artigo aclara o contexto jurídico-histórico da controvérsia em tela, os fundamentos jurídicos nos quais se ancorou a apontada opinião consultiva da CIJ, o contraponto israelita a tal entendimento, a réplica palestina às argumentações israelitas, a proposta de Estado único israelo-palestino e considerações críticas acerca do muro defensivo de Israel e do conflito judaico-muçulmano. 


\section{ANTECEDENTES HISTÓRICO-JURÍDICOS}

\section{Tentames jurídicos, diplomáticos e militares de partilha e ocupação da antiga Palestina}

Dentro do planejamento concebido pela Assembléia-Geral das Nações Unidas em 29 de novembro de 1947, via Resolução n. 181 (II), o território palestino invadido por Israel em decorrência da Guerra dos Seis Dias, estaria hoje dissociado do Estado israelense (de maioria judaica) e integrado ao Estado da Palestina (de maioria árabe) —exceto Jerusalém Oriental—, que, tal qual Jerusalém Ocidental, teria administração internacional. ${ }^{4}$

A partilha à época idealizada pela ONU fracassara. Foi tida como desproporcional pelos árabes. No semestre seguinte, em 16 de novembro de 1948, Israel proclamou sua independência, nos moldes territoriais concebidos no ano anterior pelas Nações Unidas.

Os armistícios foram decretados em 1949 e intermediados pelas Nações Unidas com arrimo nos parâmetros delineados por outro ato normativo da ONU, a Resolução no. 62, de 16 de novembro de 1948, do Conselho de Segurança.

Um desses tratados (armistícios) foi celebrado em 3 de abril de 1949, por Israel e pela Jordânia. Nele se definiu (arts. 5o. e 6o.) a fronteira entre Israel e os Estados árabes. Mais conhecida como Linha Verde (alusão à cor usada nos mapas para identificar tal fronteira), possui como sinônimos a locução Linha Demarcatória, ou ainda, no plural, a expressão Linhas Demarcatórias do Armistício.

De acordo com o sobredito Armistício Geral Israelo-Jordaniano de 1949 (art. 3o., parágrafo 2o.), nenhuma força militar ou paramilitar dos contendores poderia ultrapassar a Linha Verde. Isso não impediria posteriores alterações no traçado da fronteira dos Estados signatários, ditadas por acordos mútuos (art. 6o., parágrafo 80.).

Todavia, depois da Guerra dos Seis Dias (5 a 10 de junho de 1967), o Estado de Israel passou a controlar todos os territórios que formavam a Palestina sob administração britânica (mandato classe "A" conferido ao Reino Unido em 24 junho de 1922, pela extinta Liga das Nações, com esteio no art. 22, parágrafo 1o., da Convenção da apontada Liga, previsto 
pelo Império britânico em 1947 para estar oficialmente finalizado até 10 . de agosto de 1948, mas, depois, reprogramado para encerrar em 15 de maio de 1948, um dia depois da que acabou sendo a data da independência israelense).

Em 22 de novembro de 1967, o Conselho de Segurança da ONU aprovou, à unanimidade, a Resolução no. 242, favorável à saída de Israel dos territórios à época recém-conquistados (invadidos na Guerra dos Seis Anos): Faixa de Gaza, Península do Sinai, Cisjordânia (inclusive Jerusalém Oriental) e Colinas do Golã.

Após a Guerra dos Seis Anos, o Estado de Israel editou medidas legislativas e administrativas almejando converter toda a Jerusalém em sua capital. A Lei Básica israelense de $1980^{5}$ estatuiu: Jerusalém, completa e unida, é a capital de Israel (seç. 1a.). ${ }^{6}$ No ano seguinte o Estado de Israel anexou oficialmente Jerusalém Oriental.

A Resolução no. 478, de 20 de agosto de 1980, do Conselho de Segurança da ONU - CS/ONU—, reputou afrontosa ao Direito Internacional não apenas a referenciada Lei Básica israelense, como também todos os atos exarados por Israel para alterar o status de Jerusalém, classificados como nulos pelo referido Conselho. ${ }^{7}$

Em protesto à Lei Básica israelense de 1980 e em apoio à supracitada Resolução CS/ONU no. 478/80, muitos Estados nacionais removeram suas embaixadas de Jerusalém para o distrito de Tel Aviv, a qual, para a maioria da sociedade internacional, consiste na capital de jure de Israel.

Antes, a Resolução CS/ONU no. 298, de 25 de setembro de 1971, já ressaltara a invalidade de ações israelenses voltadas a mudar o status de Jerusalém, inclusive no tocante à expropriação de imóveis.

Não houve entendimento de Israel com a Síria para o retorno a esta das Colinas do Golã, oficialmente anexadas pelo Estado israelense em 1981, com fulcro na seç. 1a., da Lei das Colinas do Golã, de 14 de de-

5 A exemplo do Canadá, da Austrália e da Suécia, Israel não possui um único texto constitucional escrito e sim vários diplomas constitucionais esparsos, referidos pelos israelenses como Leis Básicas.

6 Israel, Basic Law: Jerusalem, Capital of Israel, 1980. Disponível em: http://www. knesset.gov.il. Acesso em: 24 de agosto de 2005.

7 Organização das Nações Unidas, op. cit., nota 1. 
zembro de $1981,{ }^{8} \mathrm{sem}$, porém, a chancela do Direito Internacional, negada pela Resolução CS/ONU no. 497, de 17 de dezembro de 1981.

O Tratado de Paz Israelo-Egípcio de 26 de março de 1979 devolveu a Península do Sinai ao Egito.

Já o Tratado de Paz Israelo-Jordaniano de 26 de outubro de 1994 estipulou como fronteira administrativa entre os Estados israelense e jordaniano os territórios sob os auspícios de Israel a partir da Guerra dos Seis Anos.

Os acordos firmados a partir de 1993 entre Israel e a Organização para a Libertação da Palestina - OLP (entidade à época de maior legitimidade na representação dos palestinos) — previram a gradativa transferência aos palestinos do controle sobre o Território Palestino Ocupado (na Cisjordânia -igualmente referida como Judéia e Samaria - e na Faixa de Gaza), prejudicada pelos desentendimentos subseqüentes ao assassinato do então Primeiro-Ministro israelense Yitzhak Rabin, em 14 de novembro de 1995, vincados pela Segunda Intifada (ou Intifada al-Aqsa, revolta popular palestina que durou de setembro de 2000 a fevereiro de 2005), pelo acentuado terrorismo islâmico (perpetrado notadamente por homens e mulheres bombas) e pela enérgica reação do Governo israelense, o qual chegou a efetuar cerco armado à Mukata (sede da Autoridade Nacional Palestina, situada em Ramalá, na Cisjordânia) e a assassinar, passo-a-passo, a então cúpula do Hamas (organização político-paramilitar palestina, atuante na Faixa de Gaza e Cisjordânia, adepta do terrorismo como mecanismo soberano de autodefesa, contra a existência do Estado de Israel e a favor da fundação de Estado palestino estribado na teocracia islâmica).

O aumento expressivo dos atentados suicidas islâmicos levou o Estado de Israel a erigir muro defensivo principalmente na Cisjordânia (incluindo-se Jerusalém Oriental) - decisão do Gabinete tomada em 14 de abril de 2002, aperfeiçoada em 23 de junho de 2002, em 14 de agosto de 2002 e 1 o. de outubro de 2003, a ponto da versão revisada do projeto à época antever na Cisjordânia barreira de segurança de $720 \mathrm{~km}$ de comprimento- 9

8 Israel, Golan Heights Law. Disponível em: http://www.jewishvirtuallibrary.org/ jsource/History/Golan_Heights_Law.html. Acesso em: 19 de julio de 2006.

9 Idem. 
Tal edificação protetora, conforme alegou o Ministério das Relações Exteriores israelense, catalisou sensível diminuição dos ataques terroristas e maior eficácia no combate à infiltração terrorista, mormente na Faixa de Gaza. ${ }^{10}$ Comparado com o ano anterior, em 2003 teria havido queda de $30 \%$ no número de atentados terroristas e decréscimo de $50 \%$ no número de vítimas mortas por terroristas.

\section{O Caso "Beit Surik"}

Poucos dias antes da Corte Internacional de Justiça proferir, em 9 de julho de 2004, a opinião consultiva sobre o muro defensivo no Território Palestino Ocupado, a Suprema Corte de Israel enfrentou litígio correlato no H.C.J. 2056, de 30 de junho de 2004, mais conhecido como "Caso Beit Sourik". ${ }^{11}$

Capitaneada pelo Presidente Aharon Barak, a Suprema Corte israelense se convenceu de que o Comando das Forças de Defesa de Israel na Cisjordânia tinha autorização legal para construir muro defensivo (edificação aludida pela Corte como cerca separatória) no Território Palestino Ocupado da Judéia e Samaria (regiões que compõem a Cisjordânia), porquanto a barreira de segurança possuiria exclusiva finalidade de proteger a sociedade israelense de ataques terroristas palestinos oriundos da Cisjordânia, correspondendo à medida de proteção de cunho temporário. A Suprema Corte israelense, entretanto, sublinhou que seria ilícita a construção do muro defensivo, se tivesse como real propósito demarcar novas fronteiras nacionais, via anexação da Judéia e Samaria.

A Suprema Corte de Israel, calçada em parecer técnico em prol da subsistência dos habitantes palestinos da Judéia e Samaria, anulou (com efeitos ex tunc) a maioria dos atos administrativos que determinou a construção daquela parcela do muro defensivo, situada na Cisjordânia.

Influenciada por estudo técnico de associação civil de oficiais da reserva das Forças de Defesa de Israel - o Conselho de Paz e Segurança-, a Suprema Corte de Israel verificou que o muro defensivo na Ju-

10 Israel, Ministry of Defence, Israel's response to the ICJ advisory opinion on the Security Fence. Disponível em: http://www.securityfence.mod.gov.il. Acesso em: 26 de agosto de 2005 .

11 Israel, Supreme Court of Israel. H. C. J. 2056/04. Beit Sourik Village Council vs. The Government of Israel and the Commander of the IDF Forces in the West Bank. Disponível em: http://www.court.gov.il. Acesso em: 22 de marzo de 2005. 
déia e Samaria poderia receber localização alternativa (à distância do oeste e do leste da Vila de Beit Sourik), o que contemplaria o imperativo de se robustecer a segurança de Israel e, ao mesmo tempo, demandaria sacrifícios consideravelmente menores de mais de 13.000 agricultores palestinos locais, que tinham de atravessar a barreira de segurança para chegarem às suas plantações e enfrentavam novas dificuldades no (antes já precário) acesso a centros urbanos importantes da Cisjordânia, como Bir Nabbala e Ramalá.

No entanto, para a Suprema Corte de Israel, a construção do muro defensivo na Cisjordânia plasmava necessidade militar que se sobrepunha - mesmo à luz do Direito Internacional — ao direito de propriedade da comunidade local (houve desapropriações para a edificação da barreira de segurança).

A juridicidade aos olhos do Direito Administrativo israelense e do Direito Internacional Humanitário foi constatada por meio do princípio tridimensional da proporcionalidade, assentado nos critérios da adequação, menor ofensividade e proporcionalidade em sentido estrito.

O critério da adequação averigua se a medida é apropriada aos fins anelados. O critério da menor ofensividade perscruta se há providência alternativa, tão adequada quanto, porém menos daninha aos interesses postos em segundo plano. E a proporcionalidade stricto sensu sopesa os valores em tensão dialética, visando a saber se os benefícios aos interesses e direitos priorizados compensam os malefícios aos interesses e direitos preteridos.

In casu, o critério da adequação analisa a conexão racional entre o percurso do muro defensivo e a finalidade da sua construção; o critério da menor ofensividade examina se, dentre as trajetórias adequadas à construção da barreira de segurança, escolheu-se a menos danosa às comunidades palestinas locais; o critério da proporcionalidade em sentido estrito apura se a localização do muro defensivo abraçada pelo Comando Militar israelense fraqueia suporte à segurança de Israel proporcional às avarias acarretadas por tal construção aos direitos das comunidades locais palestinas, tendo-se como referencial a relação custo-benefício oferecida pela localização alternativa, aventada pelo Conselho de Segurança e Paz.

Aduziu a Suprema Corte de Israel que a localização do muro defensivo no Território Palestino Ocupado sito na Samaria e na Judéia passou 
no teste da adequação, mas foi reprovada nos testes da menor ofensividade e da proporcionalidade em sentido estrito.

Em outros termos, a Corte Suprema israelense percebeu conexão racional entre o objetivo da barreira de segurança e a rota traçada para ela e viu nesse percurso o que melhor poderia resguardar a segurança israelense. Nada obstante, consignou o Pretório Excelso de Israel que a localização albergada pelo Comando Militar israelense na Cisjordânia pecou pelo desequilíbrio entre a preservação da integridade física dos israelenses e o preenchimento das necessidades básicas dos habitantes palestinos. Conquanto a localização alternativa avultada pelo Conselho de Paz e Segurança não fosse tão eficaz na proteção da segurança coletiva de Israel quanto aquela aprovada pelo Governo israelense, comparada com esta, melhor harmonizaria os valores em tensão dialética, ao minorar os sacrifícios impostos às comunidades palestinas da Cisjordânia.

\section{OS FUNDAMENTOS JURÍDICOS DA OPINIÃO CONSULTIVA DA CIJ DE 9 DE JULHO DE 2004}

A Corte Internacional de Justiça salientou a ilegalidade da aquisição de territórios pela ameaça ou uso da força. ${ }^{12}$

A construção do muro defensivo israelense no Território Palestino Ocupado significaria ofensa ao direito à autodeterminação das comunidades palestinas, ao redesenhar, em desfavor destas, a demografia local. A iniciativa israelense pavimentaria o caminho para futura anexação de áreas do Território Palestino Ocupado abarcadas pela barreira de segurança.

Israel, por intermédio de tal construção, teria infringido o Direito Internacional também ao destruir e requisitar propriedades de palestinos, restringir a liberdade de movimento dos habitantes do Território Palestino Ocupado e impedi-los de exercer o direito ao trabalho, à saúde, à educação e a padrões de vida adequados.

A CIJ não reconheceu o direito do Estado de Israel à autodefesa, haja vista os atentados terroristas não serem ataques armados de Estado nacional.

12 Organização das Nações Unidas, op. cit., nota 1. 
Não caberia à Israel cogitar estado de necessidade, pois havia outros meios disponíveis para salvaguardar seus interesses, sem afetar de forma tão gravosa a existência das comunidades palestinas locais.

Adiante tecemos comentários pontuais acerca das fontes do Direito Internacional invocadas pela referenciada opinião consultiva da Corte Internacional de Justiça.

\section{Ausência do direito à legítima autodefesa}

A Resolução no. 2625 (XXV), de 24 de outubro de 1970, da Assembléia-Geral da ONU, corrobora o art. 2o., parágrafo 4o., da Carta da Organização das Nações Unidas, de 26 de junho de 1945, a preceituar que todos Estados-membros da ONU deverão evitar em suas relações internacionais a ameaça ou o uso da força contra a integridade territorial ou a independência política de qualquer Estado, ou qualquer outra ação incompatível com os propósitos das Nações Unidas. ${ }^{13}$

A Corte Internacional de Justiça não reconheceu o direito do Estado de Israel à autodefesa legítima preconizada pelo art. 51, da Carta da ONU, ${ }^{14}$ em função da sua interpretação restritiva, elaborada pela CIJ no acórdão proferido em 27 de junho de 1986, na causa "Nicarágua v. Estados Unidos da América" ("Atividades Militares e Paramilitares na e contra Nicarágua"), ter concluído que o exercício da legítima autodefesa por um Estado depende de prévia eclosão de ataque armado determinado por outro Estado. ${ }^{15}$

13 Idem.

14 Artigo 51. Nada na presente Carta prejudicará o direito inerente de legítima defesa individual ou coletiva no caso de ocorrer um ataque armado contra um Membro das Nações Unidas, até que o Conselho de Segurança tenha tomado as medidas necessárias para a manutenção da paz e da segurança internacionais. As medidas tomadas pelos Membros no exercício desse direito de legítima defesa serão comunicadas imediatamente ao Conselho de Segurança e não deverão, de modo algum, atingir a autoridade e a responsabilidade que a presente Carta atribui ao Conselho para levar a efeito, em qualquer tempo, a ação que julgar necessária à manutenção ou ao restabelecimento da paz e da segurança internacionais. Cfr. Organização das Nações Unidas, Carta das Nações Unidas, 1945. Disponível em: http://www.dhnet.org.br. Acesso em: 24 de agosto de 2005.

15 Organização das Nações Unidas, International Court of Justice. Judgment. Case concerning military and paramilitary activities in and against Nicaragua (Nicaragua $v s$. United States of America), The Hague, 27 de junio de 1986. Disponível em: http://www.icj-cij.org. Acesso em: de 22 agosto de 2005. 


\section{Inocorrência do estado de necessidade}

Quando a Corte Internacional de Justiça asseriu a falta de estado de necessidade que justificasse a construção por Israel do muro defensivo, reportou-se, nomeadamente, ao Pacto Internacional de Direitos Civis e Políticos, de 16 de dezembro de 1966, cujo art. 4o., parágrafo 1o., consente com a derrogação dos deveres (assumidos pelos Estados-signatários no aludido Pacto) de proteção dos direitos civis e políticos enfeixados em tal tratado, se surge emergência pública (reconhecida por ato oficial) que ameaça a existência da nação (no caso, Israel).

$\mathrm{Na}$ esteira do art. 4o., parágrafo 1o., do Pacto Internacional de Direitos Civis e Políticos, as medidas derrogatórias de tais obrigações teriam de ser (1) na estrita medida em que a situação as exigisse, (2) compatíveis com outras obrigações assumidas pelos Estados-signatários perante o Direito Internacional e (3) isentas de discriminação fundada unicamente sobre a raça, a cor, o sexo, a língua, a religião ou a origem social.

Ocorre que a excepcional derrogação desses e de outros direitos humanos só seria lícita se consubstanciasse o único meio disponível para determinado Estado salvaguardar interesse essencial contra grave e iminente perigo (art. 25, dos Artigos sobre Responsabilidade dos Estados por Atos Internacionais Ilícitos, da Comissão de Direito Internacional). ${ }^{16}$

Ante os documentos a que teve acesso (baseados, sobretudo, no dossiê preparado pelo Secretariado-Geral das Nações Unidas), a Corte Internacional de Justiça não se convenceu de que a construção do muro defensivo no Território Palestino Ocupado representasse o único meio para resguardar os interesses de Israel contra o terrorismo palestino. Na ocasião, Israel se absteve de aprofundar a discussão em torno da necessidade e proporcionalidade de tal construção, porquanto julgou a CIJ ausente de autorização legal para efetuar aquela opinião consultiva. A própria CIJ optou por não aprofundar o exame da necessidade e proporcionalidade, ao contrário da Suprema Corte de Israel na jurisprudência criada em torno do "Caso Beit Surik".

\section{Direitos humanos violados}

No sentir da Corte Internacional de Justiça se revela extenso o cabedal de direitos humanos vergastado pela construção do muro defensivo. 
Com arrimo no acórdão da "Causa Relativa ao Timor Leste" (Portugal vs. Austrália), parágrafo 29, de 30 de junho de 1995, ${ }^{17}$ a CIJ afirmou que o direito à autodeterminação dos povos possui efeito erga omnes. Citando sua opinião consultiva intitulada "Conseqüências legais para Estados em face da contínua presença da África do Sul na Namíbia (África do Sudoeste), não obstante Resolução do Conselho de Segurança 276 (1970)", ${ }^{18}$ parágrafos 52 e 53, a indigitada Corte deduziu que o direito à autodeterminação alcança até povos, tais qual o palestino, desprovidos de autogoverno.

Para a CIJ, com a construção do muro de Israel, maltratou-se o direito à autodeterminação, agasalhado quer pelo Pacto Internacional de Direitos Civis e Políticos (art. 1o.), quer pelo Pacto Internacional de Direitos Econômicos, Sociais e Culturais (art. 1o.), ambos de 16 de dezembro de 1966, amparado, ainda, pela Resolução no. 2625 (XXV), de 24 de outubro de 1970, da Assembléia-Geral da ONU. ${ }^{19}$

Grifou a Corte Internacional de Justiça que a aludida Resolução no. 2625 (XXV) tem por ilegal qualquer aquisição territorial proveniente da ameaça ou do uso da força.

Antes, a Resolução no. 242, de 22 de novembro de 1967, do Conselho de Segurança, pugnara pela saída das Forças de Defesa de Israel dos territórios árabes ocupados após a Guerra dos Seis Anos, prezando-se pelas anteriores fronteiras nacionais dos Estados contendores.

Ademais, não cessa a deferência aos direitos humanos - ensinou a CIJ— em razão da deflagração de conflitos armados (art. 4o., do Pacto Internacional dos Direitos Civis e Políticos).

Impenderia ao Estado nacional assegurar os direitos humanos não só daqueles que vivem em seu território, mas também daqueles que se encontram em território estrangeiro administrado por ele (interpretação extensiva do art. 2o., parágrafo 10., do mesmo PIDCP).

17 Organização das Nações Unidas, International Court of Justice. Judgment, Case Concerning East Timor (Portugal vs. Australia), The Hague, 30 de junio de 1995. Disponível em: http://www.icj-cij.org. Acesso em: 9 de julio de 2006.

18 Organização das Nações Unidas, International Court of Justice. Advisory Opinion, Legal Consequences for States of the Continued Presence of South Africa in Namibia (South-West Africa), Notwithstanding Security Council Resolution 276 (1970) The Hague, 21 de junio de 1971. Disponível em: http://www.icj-cij.org. Acesso em: 9 de julio de 2006.

19 Idem. 
Em vista disso, importaria ao Estado de Israel promover no Território Palestino Ocupado não só os direitos dos colonos judeus, como também dos habitantes palestinos, o que envolveria fomentar os direitos coletivos contidos seja no mencionado Pacto Internacional de Direitos Econômicos, Sociais e Culturais, seja na Convenção sobre os Direitos da Criança (Resolução no. 44/25, da Assembléia Geral das Nações Unidas, de 20 de novembro de 1989), que, à semelhança do Pacto Internacional de Direitos Civis e Políticos, teriam sido ofendidos pelo isolamento proporcionado pela barreira de segurança.

Quanto aos três supracitados tratados, destacam-se estas infringências:20

1) Pacto Internacional de Direitos Civis e Políticos:

a) Direito à liberdade e à segurança, proibição de prisões ou detenções arbitrárias, desvinculadas do devido processo legal (art. 9o.);

b) Direito de circular livremente e de escolher livremente sua residência no território de determinado Estado e direito de sair de qualquer país e de entrar no próprio país (art. 12);

c) Proibição de (e proteção legal contra) intervenções arbitrárias ou ilegais na vida privada, na família, no domicílio ou correspondência e de atentados ilegais à honra e à reputação (art. 17);

2) Pacto Internacional dos Direitos Econômicos, Sociais e Culturais:

a) Limitações estatais aos direitos irradiados por tal tratado devem ser compatíveis com a natureza desses direitos e ter o exclusivo fim de promover o bem-estar geral numa sociedade democrática (art. 4o.);

b) Direito à livre escolha do trabalho e de emprego que garantam o gozo das liberdades políticas e econômicas fundamentais de cada indivíduo (art. 6o.);

c) Direito a condições de trabalho justas, favoráveis, seguras e higiênicas, que assegurem, dentre outros, salário eqüitativo, remuneração igual para trabalho de valor igual e existência decente para o trabalhador e suas famílias (art. 7o.);

d) Direito a mais ampla assistência possível à família (inclusive mães gestantes, crianças e adolescentes) (art. 10);

e) Direito de todas as pessoas a um nível de vida suficiente para si e para as suas famílias (art. 11); 
f) Direito de todas as pessoas de gozar do melhor estado de saúde física e mental possível de atingir (art. 12);

g) Direito de todos à boa educação (art. 13) e a ensino primário obrigatório e gratuito (art. 14);

3) Convenção sobre os Direitos da Criança:

a) Contrária a intromissões arbitrárias ou ilegais na vida privada, na família, no domicílio ou correspondência da criança e a ofensas ilegais à sua honra e reputação (art. 16);

b) Direito da criança a gozar do melhor estado de saúde possível e a beneficiar de serviços médicos e de reeducação (art. 24);

c) Direito da criança a nível de vida suficiente para o desenvolvimento físico, mental, espiritual, moral e social (art. 27);

d) Direito da criança a iguais oportunidades de acesso à educação (art. 28).

\section{Afrontas ao Direito Internacional Humanitário}

Relativa à proteção das pessoas civis em tempo de guerra, a Quarta Convenção de Genebra, de 12 de agosto de 1949, explicitamente rechaça tentativas do Estado ocupante mudar a demografia e o perfil da população do território ocupado (fazendo, por exemplo, deportações ou transferência da população nativa ou enxertando no território ocupado parcela da população civil do Estado ocupante), tenha as transformações intenção de beneficiar a população do Estado ocupante ou de prejudicar a população do território ocupado, a fim de facilitar, inclusive, a anexação do território ocupado (arts. 6o., 13, 47 e 49).

A Quarta Convenção de Genebra também repele medidas tendentes a forçar a população do território ocupado a trabalhar para o Estado ocupante (art. 52), a destruir a propriedade dos habitantes do território ocupado (art. 53) e avista o direito destes às ações de socorro de organismos humanitários imparciais, quando insuficientemente abastecidos (art. 59).

A construção da barreira de segurança menoscaba a liberdade dos palestinos ao livre acesso a locais sagrados (a exemplo de Jerusalém Oriental, incluída no campo de incidência do muro defensivo), em descompasso com o Tratado de Berlim de 1878 (art. 62), o Capítulo 2, da Resolução no. 181 (II), da Assembléia-Geral da ONU, de 29 de novembro de 1947, o Armistício Geral Israelo-Jordaniano de 1949 (art. 8o.), o 
Tratado Israelo-Jordaniano de 1994 (art. 9o., parágrafo 1o.) e o Mandato Britânico para a Palestina (art. 13). ${ }^{21}$

Cifram-se, ainda, disposições da Quarta Convenção de Haia sobre as Leis e os Costumes da Guerra Terrestre, de 18 de outubro de 1907:22

a) Respeito à honra e aos demais direitos da família, à vida das pessoas, à propriedade privada, às convicções e práticas religiosas (art. 46);

b) Proibição da pilhagem (art. 47);

c) O Estado ocupante deve exigir da população local contribuições pecuniárias relacionadas apenas à mantença dos seus órgãos administrativos e militares lá situados (art. 49);

d) As requisições e os serviços exigidos da população do território ocupado devem ser na proporção dos recursos locais e não podem ser contra a nação daquela (art. 52);

e) Após advento da paz, deve haver a devolução dos bens expropriados da população local pelo Exército ocupante ou a indenização equivalente (art. 53).

\section{Principais Resoluções do Conselho de Segurança da ONU violadas}

Dentre as Resoluções do Conselho de Segurança da ONU aludidas pela opinião consultiva de 9 de julho de 2004, sobressaem as que, diretamente relacionadas com o conflito israelo-palestino, rogam a Israel a proteção da população civil do Território Palestino Ocupado (Resolução no. 904, de 18 de março de 1994, assim como Resolução no. 237, de 14 de junho de 1967) e, nesse sentido, opinam pela aplicabilidade da Quarta Convenção de Genebra de 1949 no Território Palestino Ocupado e sujeição do Estado de Israel a ela (Resolução no. 904 (1994), Resolução no. 799, de 18 de dezembro de 1992, Resolução no. 681, de 20 de dezembro de 1990, Resolução no. 465, de 1o. de março de 1980, Resolução no. 452, de 20 de julho de 1979, Resolução no. 446, de 22 de março de 1979 e Resolução 237 (1967)).

Resoluções do CS/ONU repelem a presença israelense no Território Palestino Ocupado —indicada Resolução no. 452 (1979) e Resolução no. 242, de 22 de novembro de 1967 (1967) — e, nesse diapasão, repulsam medidas do Estado de Israel almejando alterar a demografia do Território

21 Conteúdo acrescentado pelo governo britânico em 14 de junio de 1922.

22 Organização das Nações Unidas, op. cit., nota 1. 
Palestino Ocupado e diminuir a população palestina do mesmo - Resolução no. 799 (1992), Resolução no. 681 (1990), Resolução no. 465 (1980) e Resolução no. 446 (1979)—.

\section{OS PRONUNCIAMENTOS JUDICIAIS ANEXOS À OPINIÃO CONSUltiva DA CIJ DE 9 DE JULHO DE 2004}

Apensa à opinião consultiva proferida pela Corte Internacional de Justiça em 9 de julho de 2004, existe a declaração do Juiz Buergenthal, expendendo as causas de sua dissidência, além de constarem 6 (seis) opiniões em separado, onde os Juízes Koroma, Higgins, Kooijmans, Al-Khasawneh, Elaraby e Owada, mesmo subscrevendo o indicado ato enunciativo da CIJ, delineiam considerações complementares sobre o caso em tela, frisando aspectos positivos ou negativos de tal opinião consultiva.

\section{Declaração do Juiz Thomas Buergenthal}

Apesar do Juiz Thomas Buergenthal ${ }^{23}$ concordar com a aplicabilidade do Direito Internacional Humanitário e do Direito Internacional dos Direitos Humanos no Território Palestino Ocupado e com a conseqüente sujeição de Israel a ambos os plexos normativos internacionais, inclusive ao lançar mão de medidas de defesa antiterrorismo, o magistrado estadunidense dissentiu dos demais membros, à época, da Corte Internacional de Justiça, posto que condicionou a emissão da opinião consultiva à ampla indagação probatória, que levasse em conta todos os argumentos jurídicos israelenses legítimos perante o Direito Internacional, calçados em necessidade militar, de autodefesa e segurança, de forma que se dimensionasse a repercussão dos atentados terroristas palestinos sobre a população de Israel. A credibilidade da opinião consultiva da CIJ de 9 de julho de 2004 dependeria do exame profundo não apenas do direito de autodeterminação do povo palestino, em face da ocupação israelense, como também do direito de autodefesa do Estado de Israel ante o terrorismo islâmico oriundo do Território Palestino Ocupado. Seria necessário

23 Buergenthal, Thomas, Declaration of Judge Thomas Buergenthal, The Hague, 9 de julio de 2004. Disponível em: http://www.icj-cij.org. Acesso em: 22 de agosto de 2005. 
apreciar cada segmento do muro de Israel, a fim de se aferirem a necessidade e a proporcionalidade, caso a caso, tendo-se presentes as questões de segurança e as especificidades topográficas. Buergenthal enfatiza que Israel, em sede de opinião consultiva —em não se tratando, portanto, de julgamento-, não era parte de processo contencioso e, por isso, não tinha dever de prestar informações a dilucidarem seu ponto de vista. Em suma, independente do Estado judeu ter prestado esclarecimentos ou não, competiria à CIJ, ao redigir opinião consultiva, arregimentar ampla colheita de subsídios fáticos favoráveis tanto a israelenses, quanto a palestinos, não podendo se esquivar do estudo minucioso da circunstância fática que motivou a construção, por Israel, de barreira de segurança no Território Palestino Ocupado.

\section{Os Votos em Separado}

O Juiz Abdul G. Koroma ${ }^{24}$ destacou as seguintes conclusões da CIJ:

1) O Território Ocupado Palestino não pode quer ser anexado pelo Estado de Israel, quer ter sua configuração territorial alterada pelo mesmo, nem sofrer quaisquer outra espécie de óbice à sua integridade territorial e à unidade nacional do povo palestino;

2) A construção do muro de Israel no Território Palestino Ocupado prejudica o exercício do direito à autodeterminação da sociedade palestina;

3) Além disso, maltrata o regime do Direito Internacional Humanitário e do Direito Internacional dos Direitos Humanos;

4) Dever da sociedade internacional assegurar a incolumidade do território palestino;

5) Caráter erga omnes dos pronunciamentos da CIJ, inclusive em sede de opinião consultiva, a título de intérprete autêntico do Direito Internacional;

6) Dever de todas as partes envolvidas no conflito israelo-palestino respeitarem o Direito Internacional Humanitário;

7) Incumbência da Assembléia-Geral da ONU de se embasar na opinião consultiva em comento para solucionar o conflito israelo-palestino.

24 Koroma, Abdul G., Separate Opinion of Judge Koroma, The Hague, 9 de julio de 2004. Disponível em: http://www.icj-cij.org. Acesso em: 22 de agosto de 2005. 
A Juíza Rosalyn Higgins ${ }^{25}$ estranhou a Corte Internacional de Justiça ser instada a se pronunciar sobre determinado aspecto do multifacetado conflito israelo-palestino, tendo sido, ao mesmo tempo, extirpadas de sua apreciação as demais nuanças do contexto envolvendo a relação contenciosa entre as sociedades de Israel e da Palestina. A despeito disso, não estaria o Tribunal de Haia imune ao múnus de sopesar os deveres de ambas as partes (Estado ocupante e sociedade ocupada) perante o Direito Internacional, inclusive o Direito Internacional Humanitário. Caberia à CIJ averiguar a inobservância ao Direito Internacional praticada não apenas pelo Governo israelense, como também pelas comunidades palestinas, levando-se em conta, ainda, os direitos assegurados ao Estado de Israel e ao povo palestino, notadamente, em relação àquele, o direito à existência e à segurança e, no outro extremo, o direito da nação palestina ter território e Estado próprios, resguardada sua autodeterminação.

Higgins também gostaria que a opinião consultiva em comento especificasse e eliminasse dúvidas quanto aos dispositivos do Direito Internacional Humanitário que, de fato, restaram descumpridos por Israel e quais, por outro lado, foram devidamente respeitados pelo Estado judeu. Frisa a magistrada britânica que o verdadeiro obstáculo ao exercício do direito à autodeterminação palestina não radica na construção da barreira de segurança israelense e sim na incapacidade de ambas as partes adimplirem seus deveres perante a ordem jurídica internacional, máxime no tocante à retirada plena de Israel dos territórios árabes por ela, ainda, ocupados e, simultaneamente, o efetivo amparo da Palestina, para que o Estado judeu assim proceda, sem comprometer a segurança da sociedade israelense.

Para Lady Higgins, plasma formalismo exorbitante não se anuir com o direito à autodefesa de Estado objeto de agressão armada cometida por habitantes residentes em território por ela ocupado, nem se apurar a responsabilidade, por tais atos, compartilhada pela Autoridade Nacional Palestina. Conquanto tenha havido aparente diminuição dos atentados terroristas em Israel, depois de construída a barreira de segurança, não teria sido elucidada a necessidade e a proporcionalidade do percurso escolhido, pelo Governo israelense, para sediar tal edificação. Em verdade, Higgins não se convenceu de que o muro de Israel, em Território Palestino

25 Higgins, Rosalyn, Separate Opinion of Judge Rosalyn Higgins, The Hague, 9 de julio de 2004. Disponível em: http://www.icj-cij.org. Acesso em: 22 de agosto de 2005. 
Ocupado, de fato configurasse medida de autodefesa, dado a caráter não-agressivo da obra, nem de que, perante o Direito Internacional, competisse ao Estados-membros das Nações Unidas — refere-se aos terceiros no conflito israelo-palestino - se sujeitarem a impositivo erga omnes de não reconhecer e não auxiliar a manutenção da barreira de segurança israelense. Nada obstante, mesmo divisando deficiências na opinião consultiva alinhavada pela CIJ em 9 de julho de 2004, revela ter aderido a ela em face da repercussão danosa, do muro israelense, à população da Cisjordânia, assim como em razão do Estado de Israel não ter esclarecido à ONU e à CIJ o caráter imprescindível, sob a ótica da necessidade militar, da localização, selecionado pelo Governo israelense, para sediar a barreira de segurança no Território Palestino Ocupado.

Apesar de cético quanto à obrigação dos Estados terceiros (que não constituem partes no conflito israelo-palestino) de concorrerem para se reprimir o desrespeito, por Israel, de normas internacionais de efeito erga omnes, o Juiz Pieter H. Kooijmans ${ }^{26}$ aduziu:

1) Israel, de fato, violou as Regulações de Haia de 1907, a Quarta Convenção de Genebra de 1949, o Pacto Internacional de Direitos Civis e Políticos de 1966, o Pacto Internacional de Direitos Econômicos, Sociais e Culturais de 1966 e a Convenção de Direitos da Criança de 1989;

2) $\mathrm{O}$ muro defensivo de Israel estabelece fato consumado e afronta o direito à autodeterminação de comunidades palestinas;

3) Viceja desproporcionalidade entre a finalidade de proteger Israel do terrorismo e a medida tomada para tanto, de erigir a barreira de segurança no Território Palestino Ocupado;

4) As Resoluções no. 1368 (2001) e no. 1373 (2001), do Conselho de Segurança da ONU, albergam direito de defesa estatal contra terrorismo internacional, sem estendê-lo a terrorismo oriundo de território administrado pelo Estado vitimado por tais atos terroristas.

O Juiz Awn Al-Khasawneh ${ }^{27}$ sobressaiu a incumbência de Israel respeitar, no Território Palestino Ocupado, o Direito Internacional Humanitário e clarificou que o óbice ao exercício da autodeterminação palestina

26 Kooijmans, Pieter, Separate Opinion of Judge Pieter H. Kooijmans, The Hague, 9 de julio de 2004. Disponível em: http://www.icj-cij.org. Acesso em: 22 de agosto de 2005.

27 Al-Khasawneh, Awn, Separate Opinion of Judge Awn Al-Khasawneh., The Hague, 9 de julio de 2004. Disponível em: http://www.icj-cij.org. Acesso em: 22 de agosto de 2005. 
repousa na continuada presença militar israelense no Território Palestino Ocupado, no qual o Estado judeu se caracterizaria por fomentar a política pública dos fatos consumados. O magistrado jordaniano vislumbra na Linha Verde o marco fronteiriço a dividir o território israelense do não-israelense.

O Juiz Nabil Elaraby ${ }^{28}$ confirmou seja o dever das Nações Unidas esgrimirem pela autodeterminação palestina e do Estado de Israel salvaguardar a integridade do Território Palestino Ocupado, seja a plausibilidade da construção do muro israelense em solo palestino ocupado, tivesse, neste caso, o Governo de Israel demonstrado a ausência de medida que preenchesse tal necessidade militar e, por outra banda, propiciasse menor dano às comunidades palestinas.

Necessidades militares e exigências militares poderiam plausivelmente ser consignadas como justificativas para a construção do muro, tivesse Israel provado que não havia como cogitar outra alternativa para salvaguardar sua segurança. Isso, como percebe a Corte, Israel falhou em demonstrar. Deve-se diferenciar entre a construção do muro como medida de segurança, alegada por Israel, e a aceitação que o princípio da necessidade militar poderia ser invocado para justificar a indesejada destruição e demolição que acompanhou o processo de construção. Necessidade militar, se aplicável, se estende à primeira e não à última. A magnitude do dano e da lesão impostos aos habitantes civis, ao longo da construção do muro e do regime a ele associado, é claramente proibida pelo Direito Internacional. A destruição de lares, a demolição da infra-estrutura, e a expropriação de terras, pomares e plantações de oliveiras que acompanharam a construção do muro, não podem ser justificadas sob qualquer pretexto. Cerca de 100.000 civis não-combatentes restaram sem casa e desafortunados. ${ }^{29}$

28 Elaraby, Nabil, Separate Opinion of Judge Nabil Elaraby, The Hague, 9 de julio de 2004. Disponível em: http://www.icj-cij.org. Acesso em: 22 de agosto de 2005.

29 Military necessities and military exigencies could arguably be advanced as justification for building the wall had Israel proven that it could perceive no other alternative for safeguarding its security. This, as the Court notes, Israel failed to demonstrate. A distinction must be drawn between building the wall as a security measure, as Israel contends, and accepting that the principle of military necessity could be invoked to justify the unwarranted destruction and demolition that accompanied the construction process. Military necessity, if applicable, extends to the former and not the latter. The magnitude of the damage and injury inflicted upon the civilian inhabitants in the course of building the wall and its associated régime is clearly prohibited under international humanitarian law. The destruction of homes, the demolition of the infrastructure, and the despoilment 
Embora o Juiz Hisashi Owada considerasse mais apropriada a análise percuciente pela CIJ acerca da finalidade oficial do muro defensivo de Israel (combate ao terrorismo), entendeu que mesmo comprovada a consistência de tal propósito, ainda assim haveria ofensa de Israel às Regulações de Haia sobre as Leis e os Costumes da Guerra Terrestre e à Quarta Convenção de Genebra sobre a Proteção de Civis em Tempo de Guerra, salvo se demonstrada justificativas cogentes. ${ }^{30}$

\section{O CONTRAPONTO ISRAELITA}

\section{Os resultados apresentados pelo Ministério da Defesa de Israel}

Em 1o. de julho de 2004, o Ministério da Defesa do Estado de Israel veiculou informações persuasivas a respeito da eficácia da barreira de segurança: ${ }^{31}$

1) Decréscimo de mais de $90 \%$ quanto ao número de atentados terroristas praticados dentro de Israel por palestinos oriundos da Samaria. De agosto de 2003 a junho de 2004 houve três atentados terroristas cometidos por palestinos provenientes dessa região da Cisjordânia. Diminuição eloqüente, em contraste com setembro de 2000 a julho de 2003, quando habitantes desse planalto perpetraram em solo israelense 73 atentados terroristas.

2) Diminuição de mais de $70 \%$ no número de israelenses mortos e mais de $85 \%$ no número de feridos por ataques terroristas.

3) Aumento expressivo na capacidade de prevenção a atentados planejados por terroristas da Samaria. Vinte e quatro cintos com explosivos e bombas foram descobertos. Dezenas de células terroristas desmanteladas, às portas da execução de novos atentados.

4) A Judéia, onde o muro defensivo está incompleto, converteu-se na principal base de envio de terroristas para Israel.

of land, orchards and olive groves that has accompanied the construction of the wall cannot be justified under any pretext whatsoever. Over 100,000 civilian non-combatants have been rendered homeless and hapless. Cfr. idem, tradução nossa.

30 Owada, Hisashi, Separate Opinion of Judge Owada, The Hague, 9 de julio de 2004. Disponível em: http://www.icj-cij.org. Acesso em: 22 de agosto de 2005.

31 Israel. Ministry of Defence, Security Fence's Effectiveness. Disponível em: http://www.securityfence.mod.gov.il. Acesso em: 26 de agosto de 2005. 


\section{A réplica do Governo de Israel}

Em comunicado enviado à Suprema Corte de Israel em 23 de fevereiro de 2005 (divulgado à sociedade cinco dias depois), o Governo israelense comentou o teor da indigitada opinião consultiva da Corte Internacional de Justiça. ${ }^{32}$

Para o Estado de Israel, o embasamento fático da assinalada opinião consultiva estava desatualizado e superficial.

Pronunciada em 9 de julho de 2004, defasou-se por se escorar em dados atinentes ao final de 2003.

Foi generalista, ignorou nuanças pertinentes, ao não atentar quer para as diferentes localizações e formatos do muro defensivo, quer para as especificidades de cada segmento da barreira de segurança. ${ }^{33}$

Olvidou o aspecto positivo da construção: de agosto de 2003 a agosto de 2004 , redução de $84 \%$ no número de israelenses, cotejado tal período com setembro de 2001 a julho de 2002.

Desconsiderou os aperfeiçoamentos: as melhorias feitas quanto ao feitio e ao posicionamento dos diversos trechos do muro defensivo, com vistas a facilitar o cotidiano das comunidades palestinas locais, implementadas em face das observações externadas pela Suprema Corte de Israel no "Caso Beit Sourik" e pela Corte Internacional de Justiça na referida opinião consultiva, conjugadas com a experiência vivenciada pelo governo israelense.

Além disso, faltou a CIJ levar em conta os abrandamentos na estrutura da barreira de segurança realizados em diversas seções, depois da queda do número de atentados terroristas em Israel.

A Autoridade Nacional Palestina alegou perante a Corte Internacional de Justiça que a barreira de segurança haveria de cobrir cerca de $43,5 \%$ da Cisjordânia. A CIJ inferiu que a porcentagem correta seria $16,6 \%$. Todavia, menos de $8 \%$ dessa região seriam, alfim, alcançadas pelo muro defensivo.

Acima de tudo, calharia à CIJ ter tido presente a realidade social de Israel: o grau de violência proporcionado pelos atentados terroristas que ensejou o surgimento desse escudo protetor contra o terrorismo.

32 Israel. Ministry of Defence, op. cit., nota 10.

33 Idem. 
O juízo de valor concatenado pela Corte Internacional de Justiça não teria sopesado a contento os valores conflitantes. Compadecida com o drama das comunidades palestinas locais e minuciosa ao compulsar as prescrições de Direito Internacional convenientes aos reclamos palestinos, a CIJ, porém, não teria ponderado, de forma percuciente, acerca das necessidades militares israelenses ensanchas ao controverso muro defensivo, do cuidado contínuo das autoridades israelenses de burilar e calibrar esse sistema defensivo e do dever inafastável do Estado de Israel de melhor proteger sua população ante o rotineiro terrorismo executado por palestinos decursivo do Território Palestino Ocupado.

\section{As ressalvas da comunidade jurídica israelita}

As críticas da comunidade jurídica israelita à opinião consultiva da Corte Internacional de Justiça em discussão se centram em quatro argumentos fundamentais:

1) Trata-se de juízo de valor parcial, ventríloquo de movimentos internacionais vertidos a isolar Israel, ${ }^{34}$ esteados em raciocínio superficial e generalista. ${ }^{35}$

2) As limitações impingidas às comunidades palestinas pela construção do muro defensivo se respaldam no Direito Internacional ${ }^{36} \mathrm{e}$ homenageiam o critério da menor ofensividade. ${ }^{37}$

3) A ausência da barreira de segurança configuraria omissão que representaria, do ponto de vista jurídico, a opção mais desarrazoada. ${ }^{38}$

34 Steinberg, Gerald M., "The UN, the ICJ and the separation barrier: war by other means", Israel Law Review, Jerusalem, vol. 38, núm. 1-2, 2005, pp. 346 y 347.

35 Kretzmer, David, "ICJ advisory opinion on construction of a wall in the occupied Palestinian Territory: the advisory opinion: the light treatment of international humanitarian law", American Journal of International Law, Washington D. C., vol. 99, núm. 1, junio de 2005, pp. 98-100.

36 Ibidem, p. 100.

37 Feinstein, Barry A. y Weiner, Justus Reid, "Israel's security barrier: an international comparative analysis and legal evaluation”, The George Washington International Law Review, Washington D. C., vol. 37, núm. 2, mayo-agosto de 2005, pp. 309-467. Disponível em: http://proquest.umi.com/pqdink?did $=845160441 \&$ sid $=1 \&$ Fmt $=4 \&$ client $I d=65353 \& R Q T=309 \& V N a m e=P Q D$. Acesso em: 27 de agosto de 2005 .

38 Idem. 
4) O muro traz efeitos protetivos benéficos tanto para judeus, quanto para palestinos. ${ }^{39}$

O magistério de Gerald M. Steinberg, da Universidade de Bar Ilan, rotula como política a opinião consultiva da Corte Internacional de Justiça. ${ }^{40}$

Steinberg insinua que o arquétipo normativo do Direito Internacional Humanitário e dos Direitos Humanos foi empregado para desnaturar o direito de Israel à autodefesa e neutralizar eficazes políticas públicas israelenses de combate ao terrorismo.

Seria resultado da estratégia de isolar e vulnerar o Estado judeu no âmbito de suas relações exteriores, por meio da manipulação das Nações Unidas e da Corte Internacional de Justiça, insufladas por organizações não-governamentais e pela mídia internacionais, cujo mentor intelectual seriam os árabes (em particular, os palestinos), que ambicionariam submeter Israel ao mesmo boicote internacional que sofreu a África do Sul sob o regime do apartheid. ${ }^{41}$

David Kretzmer, da Universidade Hebraica de Jerusalém, sobressai a deficiência da fundamentação em abstrato delineada pela CIJ. Assevera que haveria a Corte Internacional de Justiça de clarificar se as violações ao Direito Internacional Humanitário identificadas concernem a todo o muro defensivo ou a apenas a determinados segmentos. ${ }^{42}$

$\mathrm{Na}$ visão de Kretzmer, a CIJ parte da falsa premissa de que o ordenamento jurídico internacional - a começar pelo Direito Internacional Humanitário - obstaculariza peremptoriamente qualquer Estado ocupante de erigir barreiras de segurança desse feitio em territórios ocupados, como reação a constantes ataques procedentes de territórios ocupados. Não existiria no Direito Internacional mandamento emanando essa proibição. ${ }^{43}$

$\mathrm{Na}$ realidade, a administração dos territórios ocupados pelo Estado ocupante, se indispensável, pode lançar mão de expedientes para assumir a tutela de bens dos habitantes locais - hipótese contemplada pela Quar-

39 Idem.

40 Steinberg, Gerald M., op. cit., nota 34, p. 346.

41 Idem.

42 Kretzmer, David, op. cit., nota 35, p. 101.

43 Ibidem, p. 100. 
ta Convenção de Genebra (art. 64, parágrafo 2o.) e pela Quarta Convenção de Haia (art. 52) - ${ }^{44}$

Segundo prelecionam Barry A. Feinstein, da Netanya Academic College, e Justus Reid Weiner, da Universidade Hebraica de Jerusalém, seria crível a natureza temporária do muro defensivo em função de barreiras de segurança anteriormente levantadas por Israel nas fronteiras do Egito, da Jordânia e do Líbano terem sido desconstituídas (as duas primeiras, após a assinatura dos Tratados de Paz Israelo-Egípcio de 1979 e Israelo-Jordaniano de 1994; no último caso, depois da retirada das tropas israelenses do sul do Líbano em 2000). ${ }^{45}$

Feinstein e Weiner enxergam no muro defensivo sistema de segurança pacífico, o menos ofensivo, no curto prazo, para proteger Israel, os assentamentos judaicos no Território Palestino Ocupado e arrefecer os ânimos dos israelenses e palestinos. ${ }^{46}$

A ausência da barreira de segurança seria mais maléfica do que sua presença. ${ }^{47}$

Ambos acreditam que não altera o status jurídico do Território Palestino Ocupado (não haveria sua anexação ao Estado de Israel), dos palestinos locais, nem destes retira suas propriedades (privadas) imobiliárias. ${ }^{48}$

Recordam que a administração do muro defensivo mantém áreas de trânsito destinadas a facilitar o dia-a-dia dos palestinos (e israelenses) e tem aprimorado o traçado original daquele, com o fito - alicerçada na indicada opinião consultiva da CIJ e no "Caso Beit Sourik"- de amenizar os empecilhos trazidos para o viver cotidiano das comunidades palestinas locais ( $v . g$., dificuldade para agricultores palestinos exercerem seu ofício). ${ }^{49}$

\section{A reação da Suprema Corte de Israel}

No julgamento do H.C.J. 7957/04, de 15 de setembro de 2005, a Suprema Corte de Israel, mediante voto-condutor do Presidente A. Barak, sublinhou que a diferença entre o posicionamento do Pretório Excelso is-

44 Ibidem, p. 101.

45 Feinstein, Barry A. y Weiner, Justus Reid, op. cit., nota 37.

46 Idem.

47 Idem.

48 Idem.

49 Idem. 
raelense e o tino esposado pela Corte Internacional de Justiça, concernente ao muro defensivo de Israel, existe em razão de se alicerçarem em distinto fundamento fático: “A CIJ sustentou a base fática de sua opinião consultiva no relatório do Secretário-Geral, em seu discurso escrito, no relatório Dugard e no relatório Zeigler. A Suprema Corte extrai os fatos dos dados trazidos pelos peticionários palestinos, de um lado, e pelo Estado, na outra banda". ${ }^{50}$

Em outras palavras, o voto-condutor do Presidente Aharon Barak verificou que "a fundação normativa básica em que a CIJ e a Suprema Corte baseiam seus julgamentos é a mesma", ${ }^{51}$ porém "ambas as cortes alcançaram conclusões diferentes". ${ }^{2}$

A CIJ consignou que, em sua opinião, o percurso do muro contraria o Direito Internacional, porquanto a maioria do mesmo passa pela Cisjordânia. A Suprema Corte no Caso Beit Sourik assentou em seu julgamento que um pronunciamento perfunctório sobre a legalidade da cerca, de acordo com o Direito Internacional, não deve ser proferido, e que cada segmento do percurso da cerca deve ser examinado separadamente. ${ }^{53}$

Para a Suprema Corte de Israel, a opinião consultiva da Corte Internacional de Justiça foi omissa no exame de controvérsia jurídica central, ou seja, ao contrário do Pretório Excelso israelense, a CIJ se evadiu de averiguar em "cada e em todo segmento, se representa equilíbrio propor-

50 "The ICJ drew the factual basis for its opinion from the Secretary-General's report, his written statement, the Dugard report, and the Zeigler report. The Supreme Court drew the facts from the data brought before it by the Palestinian petitioners on the one hand, and the State on the other". Cfr. Israel, Supreme Court of Israel, H. C .J., 7957-04. Zaharan Yunis Muhammad Mara'abe, Morad Ahmed Muhammad Ahmed, Muhammad Jamil Mas'ud Shuahani, Adnan Abd el Rahman Daud Udah, Abd el Rahim Ismail Daud Udah, Bassem Salah Abd el Rahman Udah and the Association for Civil Rights in Israel $v s$. the Prime Minister of Israel, the Minister of Defense, the Commander of IDF Forces in the Judea and Samaria Area, the Separation Fence Authority and the Alfei Menashe Local Council. Disponível em: http://www.court.gov.il. Acesso em: 9 de julio de 2005.

51 "The basic normative foundation upon which the ICJ and the Supreme Court based their judgments is a common one". Cfr. idem.

52 "Despite that, the two courts reached different conclusions". Cfr. idem.

53 "The Supreme Court in The Beit Sourik Case ruled in its judgment that a sweeping answer to the question of the legality of the fence according to international law should not be given, and that each segment of the fence route should be examined separately". Cfr. idem. 
cional entre a necessidade securitário-militar e os direitos da população local", ${ }^{54}$ o que significaria sopesar considerações técnicas pontuais de ambas as partes e delas extrair meio-termo. Em complemento ao voto-condutor do presidente Barak, o então vice-presidente daquele Sodalício, Justice Mishael Cheshin, sobressaiu que, conquanto ausente essencial discordância entre ambos os Tribunais, no tocante ao fundamento jurídico da questão, se revelou parca a análise fática pela CIJ, isto é, municiada de amparo fático inadequado, superficial, generalista e mal-explicado, ${ }^{55}$ com tonalidades políticas e passionais.

\section{A RESPOSTA PALESTINA ÀS ARGUMENTAÇÕES ISRAELITAS}

Marwan Dalal, do Centro Jurídico para Minorias Árabes em Israel-Adalah, afiança que as normas jurídicas a que se remete Israel para sustentar a legalidade perante o Direito Internacional, do muro defensivo em estudo - e.g., art. 23 (g), das Regulações de Haia de 1907, e art. 53, da Quarta Convenção de Genebra de 1949 (alusivos ao direito de pro-

54 "Regarding each and every segment, whether it represents a proportional balance between the security-military need and the rights of the local population". Cfr. idem.

55 "We have seen that there are no essential disagreements between us and the ICJ on the subject of law, and that is fortunate. However, if that is the case regarding the legal part, regarding the factual part - the part which is the basis upon which the judgment is built- I should like to disagree with the ICJ. 4. As we saw in my colleague's survey, the factual basis upon which the ICJ built its opinion is a ramshackle one. Some will say that the judgment has no worthy factual basis whatsoever. The ICJ reached findings of fact on the basis of general statements of opinion; its findings are general and unexplained; and it seems that it is not right to base a judgment, whether regarding an issue of little or great importance and value, upon findings such as those upon which the ICJ based its judgment. The generality and lack of explanation which characterize the factual aspect of the opinion are not among the distinguishing marks worthy of appearing in a legal opinion or a judgment. Moreover, generality and lack of explanation infuse the opinion with an emotional element, which is heaped on to an extent unworthy of a legal opinion. I might add that in this way, the opinion was colored by a political hue, which legal decision does best to distance itself from, to the extent possible. And if all that is not enough, there is the ICJ's almost complete ignoring of the horrible terrorism and security problems which have plagued Israel - a silence that the reader cannot help noticing - a foreign and strange silence. I can only agree with Judge Buergenthal, and partly with Judge Higgins, Judge Kooijmans, and Judge Owada, that the factual basis upon which the judgment was built is inadequate to the point that it is inappropriate to pass judgment upon it, even by way of opinion". Cfr. idem. 
priedade do povo sob ocupação estrangeira) - não vislumbra como providência militar absolutamente necessária o combate a terrorismo não-estatal, até porque uma medida bélica extraordinária, justamente pelo seu caráter incomum e emergencial, possui duração mais efêmera que a existência de uma barreira de segurança como a que foi erigida pelo Estado israelense. ${ }^{56}$

As transformações por que passou o muro defensivo desde a manifestação da opinião consultiva da Corte Internacional de Justiça não teriam extirpado deficiência precípua de tal construção: situa-se no seio do Território Palestino Ocupado, às expensas dos direitos de seus habitantes, acolhidos pelo plexo normativo do Direito Internacional Humanitário.

Conforme o Centro Palestino para Direitos Humanos - $\mathrm{CPDH}-$, não houve facciosismo da Corte Internacional de Justiça, uma vez que se fincou em juízos de valor expressos por diversos órgãos e entidades das Nações Unidas, o que impediria a opinião consultiva da CIJ de se abeberar exclusivamente em fonte monopolizada por interesses políticos específicos. ${ }^{57}$

O CPDH salienta o boicote do Estado de Israel ao processo de formulação da opinião consultiva.

Recorda que o governo israelense acusa a Corte Internacional de Justiça de parcialidade, mas se negou a aceitar sua jurisdição, in casu, não-contenciosa (a redundar em opinião consultiva e não em decisão judicial), e, em conseqüência, recusou-se a contestar, ponto-a-ponto, o mérito das alegações feitas perante a CIJ em desfavor do muro defensivo israelense.

Consoante sublinha o $\mathrm{CPDH}$, a barreira de segurança terá como legado o redesenhamento da demografia do Território Palestino Ocupado, servindo de pretexto para confiscá-los das comunidades palestinas, substituídas por assentamentos judaicos.

56 Dalal, Marwan, "Another Brick in the Wall: Between Israeli Law and the ICJ's Advisory Opinion”, Adalah's Newsletter, Shafa'amr, vol. 15, julio de 2005. Disponível em: http://www.adalah.org. Acesso em: 27 de agosto de 2005.

57 Palestinian Centre for Human Rights, Securing the Wall from International Law: an initial response to the Israeli State Attorney, Gaza City: PCHR, 2005 (PCHR Position Paper). Disponível em: http://www.pchrgaza.org. Acesso em: 28 de agosto de 2005. 
A hipótese da anexação do Território Palestino Ocupado seria robustecida pela simultânea retirada das colônias judaicas da Faixa de Gaza e aumento dos assentamentos israelitas na Cisjordânia. ${ }^{58}$

O muro defensivo seria muito caro e sofisticado para constituir medida temporária. Fosse provisório, seria construído na Linha Verde, onde a despesa seria deveras menor.

Para o Centro Palestino de Direitos Humanos, em vez do 3,2\% aventados por Israel, na realidade $7,4 \%$ do Território Palestino Ocupado foi coberto pela barreira de segurança, podendo, em breve, abarcar mais $38,6 \%$ (proporção correspondente a assentamentos ainda não protegidos pelo muro defensivo, como os do Bloco Ariel e os povoamentos judaicos do Vale do Jordão, área proibida para palestinos).

Ressalta o CPDH que Israel não contabiliza em suas estatísticas os territórios oficialmente anexados, como Jerusalém Oriental, cujo acesso, agora, em razão da construção muro, seria defeso aos palestinos da Cis-

58 A propósito, informa a Folha de S. Paulo: “A população de colonos judeus na Cisjordânia teve um aumento de 12,8 mil pessoas no período de um ano, segundo anunciou ontem o governo israelense. Na terça, Israel concluiu a desocupação dos 21 assentamentos de Gaza e de quatro da Cisjordânia. Por outro lado, o governo israelense pouco fez para mostrar que pretende reduzir a colonização na Cisjordânia $-o$ que contraria os palestinos-. O Ministério do Interior israelense divulgou que a população judaica da Cisjordânia chegou em junho a 246 mil pessoas, um crescimento de $5 \%$ em 12 meses. Para o órgão, o aumento se deve a nascimentos e ao fluxo de novos colonos. $\mathrm{O}$ inchaço pode se agravar nos próximos meses, já que muitos colonos que tiveram de deixar Gaza foram instalados provisoriamente na Cisjordânia e podem optar por permanecer. O assentamento de Ariel, por exemplo, recebeu cerca de 400 colonos provenientes de Netzarim, em Gaza. Ontem, houve também a primeira morte relacionada à retirada israelense. Yelena Bosinova, 54, morreu por queimaduras sofridas em protesto no dia 17. O anúncio do aumento dos colonos deu munição para críticas dos palestinos, cuja população estimada na Cisjordânia é de 2,2 milhões de pessoas. 'Esses assentamentos e a paz são duas retas paralelas que não se encontram', disse o negociador Saeb Erekat. Zalman Shoval, conselheiro de Sharon, porém, reforça a visão de que a posição mais forte é a favorável à expansão dos principais assentamentos na Cisjordânia. 'Nós não estamos preocupados com a situação dessas colônias.' Enquanto a situação da Cisjordânia segue incerta, os palestinos começam a estudar novos nomes para os assentamentos de Gaza. Dois já cogitados são os de Yasser Arafat e do xeque Ahmed Yassin, o fundador do grupo terrorista Hamas morto por Israel em 2004". "Assentamentos judeus crescem na Cisjordânia", Folha de S. Paulo, São Paulo, 27 de agosto de 2005. Disponível em: http://www.uol.com.br/fsp. Acesso em: 27 de agosto de 2005 . 
jordânia. Em seu prognóstico, sobrará para a Autoridade Nacional Palestina a administração de apenas 54\% do Território Palestino Ocupado.

\section{A PROPOSTA DE ESTADO ÚNICO}

Salim Tamari, da Universidade de Birzeit, tem por inócua a fundação do Estado da Palestina, dado o grau de dependência palestina em relação à economia e à infra-estrutura. ${ }^{59}$

Mais renomado intelectual palestino, Edward Said, avalia ser impossível a separação integral das comunidades israelenses e palestinas em Estados apartados. O destino de ambos os povos estaria indissoluvelmente interligado. A estabilidade e segurança só se concretizariam por meio da "coexistência pacífica e reconciliação genuína", ${ }^{60}$ artífice de autodeterminação e soberania para todos.

A solução residiria em converter Israel em Estado laico nos moldes ocidentais. Em vez de se esgrimir por Estado palestino muçulmano ou Estado israelense judaico, fazer-se-ia do Estado já estruturado na Palestina —o Estado de Israel — portador de regime político democrático que assegurasse a todos — de todas as etnias e credos - direitos e deveres iguais, pautado por Constituição escrita a encapsular direitos fundamentais de forma igualitária, escoimado de tratamentos diferenciados, de preferências ou discriminações legais ditadas pela religião ou etnia. Estado que garantisse à comunidade judaica internacional o almejado porto-seguro ao judaísmo aspirado pelo sionismo e, ao mesmo tempo, devolvesse aos palestinos não só o direito de ser nacional de determinado Estado, como também o direito de exercer a plena cidadania, sem ser tratado como estrangeiro em seu próprio país.

Tal proposta se demonstra condizente com o ideal de Estado israelo-palestino depurado de fanatismo religioso e de nacionalismo sectário, ancorado no federalismo comunitário, a conferir às comunidades étnico-religiosas autonomia constitucional para manterem sua vida comuni-

59 Tamari, Salim, "The binationalist lure: a response to "The case of binationalism", Boston Review, Boston, diciembre de 2001 a enero de 2002. Disponível em: http://bostonreview.net/ndf.html\#Binationalism. Acesso em: 18 de julio de 2006.

60 Said, Edward, "The one-State solution", The New York Times, Nueva York, 10 de enero de 1999. Disponível em: http://www.members.tripod.com/ TheHOPE/said.htm. Acesso em: 28 de agosto de 2005. 
tária fiel às suas tradições culturais, vivendo, entretanto, todas integradas no mesmo território, sem haver compartimentos estanques, isto é, sem haver unidades federativas onde imperasse a homogenia étnico-religiosa: seria vedado aos judeus e muçulmanos evitarem o contato diário de uma comunidade com a outra; o federalismo comunitário apenas chancelaria autonomia para praticarem os atos da vida civil de maneira harmônica com sua cultura, impedidos, contudo, de se encastelarem em enclaves marcados pela pureza étnico-religiosa (medida profilática contra o apartheid).

Endossando o ideal de Edward Said, a cientista política Virginia Tilley obtempera que não basta o desmonte dos instrumentos estatais israelenses concebidos para preservarem e incrementarem a prevalência da maioria judaica sobre a minoria muçulmana no Estado de Israel. Importa, ao mesmo tempo, tanto remodelar pretensões palestinas de amordaçar israelitas, quanto desarmar as células terroristas árabes. ${ }^{61}$

O Estado binacional possivelmente teria, em pouco tempo, população árabe superior à israelita. Isso poderia reascender o nacionalismo palestino e tornar os judeus reféns da nova maioria, agora muçulmana. $\mathrm{O}$ fim da concepção judaica de ordem estatal não pode ser a alvorada de República islâmica. Não adiantaria se desconstruir a preponderância dos interesses judaicos sobre os muçulmanos, em Israel, somente para se inverterem os papéis, onde a maioria árabe marginalizaria e oprimiria a minoria israelita.

Daniel Lazare, no The Nation, sobreeleva que a solução do Estado único israelo-palestino repercutiria a ideologia contemporânea do multiculturalismo, compromissada em transpor as fronteiras étnico-religiosas em direção à concepção pluralista de cidadania, avessa a ideologias belicistas, racistas e teocráticas. ${ }^{62}$ Em relação ao Estado binacional, Tony Judt, da Universidade de Nova Iorque, acentua a importância do nasci-

61 Tilley, Virginia, "The one-State solution", London Review of Book, Londres, vol. 25, núm. 21, 6 de noviembre de 2003. Disponível em: http://www.lrb.co.uk. Acesso em: 28 de agosto de 2005.

62 Lazare, Daniel, "The one-State solution", The Nation, Nueva York, 3 de noviembre de 2003. Disponível em: http://www.thenation.com. Acesso em: 28 de agosto de 2005 . 
mento de nova classe política judaico-árabe. ${ }^{63}$ Conquanto a segurança judaico-árabe tenha "de ser garantida por força internacional", ${ }^{64}$ o Estado binacional, se constituído de modo legítimo, apresentaria, comparado ao Estado de Israel e à Autoridade Nacional Palestina, maior facilidade para fiscalizar militantes de todo o espectro político-ideológico, uma vez que menor o combustível para o sentimento de marginalidade, catalisador de extremismo.

Lama Abu-Odeh, da Universidade de Georgetown, alicerça o Estado binacional em concepção federalista de inspiração liberal e estadunidense, ajustada às demandas impostas pelas divisões étnico-religiosas do Oriente Médio. ${ }^{65}$ As comunidades judaicas e palestinas formariam unidades com autonomia para estipular, dentro da moldura constitucional, as próprias diretrizes administrativas, financeiras, econômicas e culturais, respeitado o direito de opção e movimentação dos cidadãos de origem judaica e palestina (teriam a faculdade de residirem na unidade de sua preferência, observada a separação territorial entre judeus e palestinos, salvo no caso dos judeus árabes, que poderiam decidir por se radicarem em unidades palestinas). Haveria distribuição de renda (transferência de recursos financeiros de comunidades judaicas para palestinas), mediante arrecadação tributária e indenizações, com o propósito de se arrefecerem tensões e desigualdades sociais. Para Abu-Odeh, o binacionalismo impeliria a comunidade israelense a estar à altura do discurso da democracia liberal e impulsionaria a comunidade palestina a abandonar a ideologia belicista. ${ }^{66}$ Segundo a mesma intelectual, o Estado binacional galvanizaria a substituição dos embates entre judeus e palestinos pelos conflitos de interesse típicos da sociedade civil, em face do contraste entre segmentos de diferentes perfis ( $v$. g., socioeconômicos, ideológicos e culturais). ${ }^{67}$

63 Judt, Tony, "Israel: The Alternative", The New York Review of Books, Nueva York, vol. 50, núm. 16, 23 de octubre de 2003. Disponível em: http://www.nybooks. com/articles/16671. Acesso em: 17 de julio de 2006.

64 Idem.

65 Abu-Odeh, Lama, "The case for binationalism: why one state - liberal and constitutionalist - may be the key to peace in the Middle East", Boston Review, Boston, diciembre de 2001-enero de 2002. Disponível em: http://bostonreview.net/ndf.html \#Binationalism. Acesso em: 18 de julio de 2006.

66 Abu-Odeh, Lama, "Lama Abu-Odeh Replies", Boston Review, Boston, diciembre de 2001-enero de 2002. Disponível em: http://bostonreview.net/ndf.html\#Binationalism. Acesso em: 18 de julio de 2006.

67 Idem. 
Omar Bargouti, ${ }^{68}$ pesquisador independente, atribui ao Estado binacional as seguintes atribuições:

1) Primar pelo retorno e ressarcimento dos refugiados palestinos e, em paralelo, evitar desnecessários sofrimentos à comunidade judaica;

2) Conceder plenos, igualitários e inequívocos direitos a todos os nacionais, judeus e árabes;

3) E fomentar respeito às peculiaridades culturais, religiosas e étnicas de cada comunidade.

O escritor sionista Daniel Gavron, ${ }^{69}$ tendo por irreversível a alvorada do Estado binacional ante a explosão demográfica palestina, aduz:

1) Denominando-se Estado de Jerusalém o Estado israelo-palestino, evitar-se-ia adoção de rótulos que desagradasse a israelitas e a palestinos. Os idiomas oficiais seriam o inglês, o hebraico e o árabe;

2) Existindo Estado único, desapareceriam disputas territoriais entre palestinos e israelenses;

3) Revogando-se a Lei do Retorno de $1950^{70}$ (cuja seç. 1a. assegura a todos os judeus direito de imigrarem para Israel), os palestinos, em contraprestação, abandonariam a bandeira ideológica do direito de regresso. O processo de naturalização seria o típico dos Estados laicos;

4) A ordem jurídica ampliaria, ao máximo, a autonomia étnica, religiosa, cultural e educacional, a fim de que contemplasse as peculiaridades das comunidades árabes muçulmanas e cristãs, judaicas seculares e ortodoxas, assim como a de outros segmentos sociais, a exemplo de cristãos egressos da ex-União Soviética e de outros grupos de trabalhadores imigrantes.

Se vicejasse o formato de Estado binacional, o Estado de Israel inauguraria nova etapa em suas relações exteriores, entrosando-se plenamente na sociedade internacional. Consistiria em mecanismo eficaz seja para atalhar o anti-semitismo em todo o globo, seja para se buscarem parcerias perenes e construtivas entre judeus e árabes, permitindo-se aos palestinos vivenciarem a democracia de estilo ocidental, sonho há muito aca-

68 Bargouti, Omar, The fundamental Obstacle to a one State Solution. Disponível em: http://fromoccupiedpalestine.org/. Acesso em: 18 de julio de 2006.

69 Hirschberg, Peter, "One state awakening", Ha'aretz, Tel Aviv, 16 de diciembre de 2003. Disponível em: http://www.zmag.org/content/showarticle.cfm? ItemID $=4693$. Acesso em: 17 de julio de 2006.

70 Israel, The Law of Return 5710, 1950. Disponível em: http://www.knesset.gov.il. Acesso em: 18 de julio de 2006. 
lentado por comunidades palestinas cuja parcela considerável cresceu em campos de refugiados das Nações Unidas e lá se educaram, adquiriram a consciência crítica de que possuem direitos humanos, em falta na maioria da sociedade civil das nações árabes, dominadas por regimes autoritários.

Ebrahim Moosa, da Universidade de Duke, grifa: "Qualquer um acostumado com o território e a história da luta palestina bem sabe que a única solução viável e igualitária à ocupação de Israel é um Estado unitário, secular e democrático, baseado na eqüidade, não no nacionalismo. Tal solução teria de desmantelar as instituições raciais do sionismo, bem como as infra-estruturas de privilégios erigidas pela elite palestina", ${ }^{71}$

\section{CONSIDERAÇÕES CRÍTICAS}

\section{Perspectivas de curto, médio e longo prazos}

Emprega-se à saciedade o arcabouço normativo do Direito Internacional dos Direitos Humanos e do Direito Internacional Humanitário para certificar ou esvaziar a juridicidade do muro defensivo de Israel no Território Palestino Ocupado, tendo-se como substrato anseios políticos, econômicos, militares, culturais, psicológicos e religiosos ora ponderáveis, ora inconfessáveis.

Proceder à análise jurídica do muro defensivo de Israel significa ter presente o imperativo de que a sociedade internacional e os organismos atrelados à $\mathrm{ONU}$ amparem o povo palestino do ponto de vista do Direito Internacional dos Direitos Humanos e do Direito Internacional Humanitário, sem ignorar, todavia, as ponderáveis necessidades militares e de segurança que legitimam, perante a sociedade e, máxime, o Poder Judiciário de Israel, a existência da barreira protetora, encravada, sobremaneira, no Território Palestino Ocupado. Apenas o exame caso a caso pela Corte Internacional de Justiça, considerando a localização e o impacto de determinado trecho do muro defensivo israelense — quer a posição escolhida pelo Governo de Israel, quer as demais alternativas geográficas inferidas como viáveis, mediante apreciação técnica idônea e acurada - sob a ótica da sobrevivência dos povos tanto israelense, quanto palestino, extirpa-

71 Moosa, Ebrahim, "No easy solution: a response to "The case of binationalism", Boston Review, Boston, diciembre de 2001-enero de 2002. Disponível em: http://bostonreview.net/ndf.html\#Binationalism. Acesso em: 18 de julio de 2006. 
rá o Tribunal de Haia de críticas de parcialidade e superficialidade, ora inevitáveis em face da interpretação literal do Direito Internacional, veiculada na opinião consultiva de 9 de julho de 2004, adstrita à exposição de passagens de atos normativos e opinativos, de âmbito supranacional, a demonstrarem que a barreira de segurança israelense fere a dignidade do povo palestino - estudo jurídico salutar, não tivesse a CIJ olvidado ponderar, de modo percuciente, acerca dos possíveis imprescindíveis efeitos benfazejos do muro de Israel sobre a sociedade israelense, em função dos constantes atentados praticados em solo israelense por terroristas egressos do Território Ocupado Palestino e de regiões limítrofes gerenciadas pela Autoridade Nacional Palestina, aparelho quase-estatal incapaz de unificar o controle sobre as milícias palestinas e desbaratar as células terroristas-.

Embora, no curto prazo, não se divise para Israel medida antiterrorismo islâmico de igual eficácia e, ao mesmo tempo, menos ofensiva aos palestinos que a barreira de segurança localizada, principalmente, no Território Palestino Ocupado, sua existência apenas se legitima perante a sociedade internacional e resulta em efeitos benignos de longo prazo para a sociedade israelense, se ocorrer —em paralelo e mediante hábil coordenação diplomática e militar da Organização das Nações Unidaso efetivo, total e permanente término da presença e atuação bélica de Israel na Cisjordânia, Faixa de Gaza, Colinas do Golã e Líbano, transferindo-se à Autoridade Nacional Palestina a plena administração de Jerusalém Oriental e do Território Palestino Ocupado, sem a ameaça ou o risco de Israel voltar a invadir e/ou a atacar comunidades não-judaicas do Oriente Médio, tais quais aquelas situadas em regiões palestinas (Cisjordânia e Faixa de Gaza), sírias (Colinas do Golã) e libanesas (sul do Líbano, inclusive Fazendas Shebaa). Simultaneamente, calha cessar 1) quer a política externa de fomento ao terrorismo islâmico, praticada pela Síria e pelo Irã, 2) quer o suporte das sociedades palestina e libanesa a células e organizações terroristas, sobretudo àquelas enraizadas no tecido social e no aparelho governamental (a exemplo do Hamas, na Palestina, e do Hezbollah, no Líbano). Tal cenário apenas se concretizará, quando e se houver evento global (consciência da cidadania planetária) ou regional (incidente nuclear no Oriente Médio) de tamanha envergadura, que torne irreversível o caminho para a pacificação entre árabes e judeus. Por enquanto (julho de 2006), evidencia-se a tendência de que o conflito no Oriente Médio, entre muçulmanos e judeus, seja levado às últimas conse- 
qüências, nem que isso signifique assegurar-se o gradativo extermínio mútuo.

Se ainda houver futura oportunidade para a duradoura chancela do Estado de Israel à coordenação diplomática e militar da ONU para 1) a desocupação dos territórios invadidos por aquele na Guerra dos Seis Dias (inclusive Jerusalém Oriental) e 2) a fundação do Estado da Palestina, o Estado de Israel, no médio prazo, se colocará em posição vantajosa, ao se municiar da credibilidade de quem se revela verdadeiramente comprometido com o ordenamento jurídico internacional e, por conseguinte, mostrar-se-ia bastante menos vulnerável ao discurso legalista e, mormente, de vitimização, utilizado, em regra, tanto pela Autoridade Nacional Palestina, quanto pelo Hamas e Hezbollah (Hizbollah, Hizbullah ou Herzb'Allah), assim como por atores internacionais simpatizantes da causa palestina.

As fontes de legitimação do terrorismo islâmico internacional não desapareceriam. No entanto, ver-se-iam desprovidas do atual considerável poder persuasório sobre as mentes e corações de jovens palestinos, árabes e muçulmanos do Oriente Médio, convencidos, em função da desesperadora falta de perspectivas luminosas, de que não haveria alternativa senão a adesão à luta kamikaze, direcionada à degenerescência de Israel, difusão da teocracia islâmica e propagação de atentados terroristas em sítios ocidentais e orientais, mesmo que tal linha de conduta redunde, no Oriente Médio, na progressiva aniquilação socioeconômica, psicológica e física de ambos os contendores (risco, ainda que inconsciente, assumido não somente pela ala extremista das sociedades muçulmanas do Oriente Médio, como também pelo segmento fundamentalista da sociedade israelense).

No longo prazo, amadurecerá a ilação de que o Estado binacional (israelo-palestino) pluralista e laico será a solução definitiva para o conflito judaico-muçulmano. Enquanto as psiques judaica e muçulmana não conseguirem reunir condições suficientes para introjetarem essa visão holística e madura, a paliativa coexistência dos Estados judeu e palestino consistirá em laboratório fecundo para ambos os povos se condicionarem a compartilhar valores pacíficos, fraternos, de ponderação e de prudência moral. Assim, incentivados pelas reiteradas dificuldades práticas de se bifurcarem em compartimentos estanques povos comprimidos em espaço geográfico reduzido, deduzirão a indispensabilidade e inevitabilidade da fusão de ambos os aparelhos estatais. Mas essa solução não será para a 
atual geração da opinião pública e dos mandatários israelenses e palestinos. Apenas as novas gerações terão condições psicológicas e políticas de, ao menos, se planejarem para a fundação do Estado israelo-palestino.

Ressalte-se que a intervenção das Nações Unidas deve se orientar por postura conciliatória, eqüitativa, que conquiste o apoio, de um lado, da opinião pública do Ocidente (notadamente dos Estados Unidos e da Europa) e de Israel, e, de outra banda, granjeie o beneplácito da comunidade árabe e muçulmana internacional (em particular, do Oriente Médio). De suma relevância que a Força das Nações Unidas em Israel e na Palestina tenha suporte político da sociedade internacional, autorização legal e aparato militar e de segurança suficientes para atuar de modo eficaz e decisivo, para que não tenha função simbólica, papel secundário, conduta parcial ou mesmo apática. Merece assimilar as virtudes e, em especial, evitar as falhas praticadas pela Força Interina das Nações Unidas no Líbano (em inglês, United Nations Interim Force in Lebanon -UNIFIL_), que buscou, de 23 de março 1978 a 31 de julho de 2006, sem sucesso de vulto, o desmonte do Hezbollah, a unificação do controle militar do Líbano sob a égide do governo libanês e o fim das retaliações armadas de Israel.

Enquanto a Organização das Nações Unidas não for reformulada a contento e, máxime, enquanto as sociedades do Oriente Médio, em especial a israelense e a palestina, não passarem por sincrônica e profunda reforma ética e psicológica individual e coletiva, será impossível desconstruir o muro defensivo de Israel, porquanto o Governo judeu e as forças políticas palestinas a cada dia continuarão a robustecer a legitimidade, no seio de seus povos, da manutenção, à moda apartheid, de tal barreira de segurança, ao exercitarem expressões diferentes de terrorismo, fortalecendo o extremismo e a violência judaicos e árabes. A elite política de Israel e da Palestina sabe da ineficácia, no presente contexto, de propostas de paz unilaterais, bilaterais e multilaterais. Entretanto, os Governos israelense e palestino oficialmente sinalizam simpatia à solução diplomática porque desejam obter tempo para conceber novas estratégias de agressão bilateral e manipulação da opinião pública de ambos os contendores.

Em primeiro plano, essencial, rememore-se, profunda mudança de mentalidade entre judeus e palestinos. Sem a sincera disposição para que ambas as sociedades desfrutem de condições dignas de existência e desenvolvimento socioeconômico, respeitada a diversidade cultural me- 
diante convívio fraterno, igualitário e solidário, se denota quase inócua a intervenção humanitária da sociedade internacional, haja vista, no conflito israelo-palestino, o niilismo (imantado ao ódio, à intolerância e à soberba, bem assim à ilusão de grandeza e de supremacia) ser levado, recorde-se, às últimas conseqüências, dado o sentimento dos contendores de superioridade moral e a convicção de que possuem respaldo divino para um exercer no outro inclemente ofensiva de implosão psicológica, assassinato em série e expulsão territorial, independente das conseqüências deletérias do ponto de vista econômico, social, psíquico e ético.

Em segundo plano, convém a mediação do conflito israelo-palestino por intermédio de órgão supranacional permanente, espécie de Conselho Planetário, formado por reservas morais da humanidade, representativos de todo o caldo cultural mundial, que supervisione as regiões do globo onde exista a eclosão efetiva ou iminente de conflitos armados lato sensu (inclusive ataques terroristas e guerras civis), sobrepondo-se ao lobby político e econômico das potências mundiais, continentais e regionais, a tradicionalmente imobilizar o Conselho de Segurança da ONU. O desmonte do atual percurso do muro de Israel, sua transposição para as fronteiras de Israel anteriores à Guerra dos Seis Dias e a demolição de qualquer barreira de segurança dessa natureza deverão ser controlados pelo Conselho Planetário, por meio de corpo de segurança próprio, integrado por militares de carreira, desvinculados, no entanto, de Forças Armadas estatais e milicianas - isto é, pertencentes a quadro funcional perene, atrelado à estrutura administrativa das Nações Unidas e diretamente subordinado ao Conselho Planetário-. Efetivos da Força de Segurança Planetária deverão gerenciar áreas de risco do globo, onde campeiem contendas armadas entre povos (fora e dentro das fronteiras estatais). Denota-se primordial que a Força de Segurança Planetária administre as fronteiras dos Estados de Israel e da Palestina, de modo que sirva de anteparo, em zona neutra, desmilitarizada, quer para a penetração, em Israel, de terroristas e milicianos palestinos, quer para a incursão, na $\mathrm{Pa}$ lestina, das Forças de Defesa israelenses.

O futuro do Oriente Médio será somente dadivoso se houver ruptura visceral com a atual visão de mundo predominante nas comunidades muçulmanas, árabes e judaicas lá situadas, ao frutificar a percepção de que todos os habitantes do Oriente Próximo merecem iguais direitos de conviverem de modo digno, fraterno, pacífico e ético, inclusive ponderado e prudente. Esse novo padrão de conduta e entendimento surgirá apenas se 
preponderar a noção de que os todos os povos formam única família planetária ou, acaso a crescente destruição mútua entre muçulmanos e judeus, forcem os sobreviventes de ambas as partes a aderirem à postura de quem nada tem a defender senão a paz perpétua, ante a ausência de alternativa minimamente viável, até no curto prazo.

Na primeira etapa, importa que o Território Palestino Ocupado receba proteção armada das Nações Unidas, caso, antes o Governo de Israel e as facções político-paramilitares palestinas implementem verdadeiro tratado de paz. Cumpre à ONU intermediar acordo multilateral que possibilite a ela a concessão de expressa anuência das partes para que lhe incumba salvaguardar a população civil palestina e dos assentamentos judaicos, gerenciar tanto o esvaziamento ou transferência destes, quanto as fronteiras entre Israel e o Território Palestino, bem como implantar entre eles zona desmilitarizada, administrar Jerusalém Oriental, em nome da Autoridade Nacional Palestina, e, pari passu, amparar esta na construção das vigas mestras da organização política, administrativa e jurídica do Estado da Palestina, de natureza democrática e laica, a reconhecer o Estado de Israel e o direito dos judeus de a esta imigrarem. Cabe ao Estado de Israel completar sua retirada militar e dos assentamentos judaicos do Território Palestino Ocupado, das Colinas do Golã e firmar tratado de paz com o Líbano, que implique, por outro lado, o desarmamento do Hezbollah.

$\mathrm{Na}$ segunda etapa, marcada pela coexistência dos Estados de Israel e da Palestina, o direito de regresso de judeus e palestinos deverá ser enfrentado - o Estado de Israel colaborará financeiramente com o fundo do Estado palestino destinado à repatriação de refugiados-. Conveniente que assim seja estabelecido: o direito de retorno dos judeus será válido apenas no Estado de Israel e o direito de retorno dos palestinos será válido apenas no Estado da Palestina. As proporções territoriais de ambos os Estados devem ser equivalentes, sendo admissível configuração territorial diferente das fronteiras hoje reconhecidas pelo Direito Internacional, anteriores à Guerra dos Seis Dias, acaso levadas a efeito negociações bilaterais nesse sentido, sem que, contudo, haja tratativas almejando enfraquecer um ou outro Estado, pela transferência de regiões de difícil ocupação e desenvolvimento. Os Estados de Israel e da Palestina deverão ser desmilitarizados, medida profilática para se evitar que desentendimentos políticos futuros acarretem conflitos armados (inclusive disputas territoriais). A proteção de ambos os Estados convém incumbir à Força da Se- 
gurança Planetária ou por militares de outros países, sob a batuta da ONU, procedentes, na segunda hipótese, de nações cuja política externa não esteja (ou tenha sido até pouco tempo) atrelada à exclusiva ou prevalecente defesa de interesses palestinos ou israelitas.

$\mathrm{Na}$ terceira etapa, marcada pela fusão dos Estados de Israel e da $\mathrm{Pa}$ lestina, oportuno mesclar a influência do constitucionalismo liberal e consuetudinário anglo-saxônico (herança do Império britânico inserta na ordem jurídica israelense e sedimentada pela influência cultural estadunidense) com a emulação do que houver de aplicável ao contexto israelo-palestino, emanado da experiência, ainda incipiente, do federalismo comunitário libanês, condimentada pelo estudo do sistema jurídico indiano, no tocante às medidas estatais contra discriminação sócio-étnico-religiosa, e sul-africano, pertinente às políticas públicas de reconciliação nacional e inclusão social de segmentos marginalizados.

\section{Modelos do Direito Comparado}

Com fulcro na Constituição da República da África do Sul de 1996 (capítulo 1, seç. 1a.), Israel e a Palestina devem constituir Estado único, soberano e democrático, assentado nos valores da dignidade humana (aprimoramento da igualdade e avanço dos direitos humanos e liberdades), não-racismo e não-sexismo, primazia da Constituição e do Estado de Direito, sufrágio adulto universal, comitê eleitoral nacional, eleições regulares e sistema multipartidário próprio de governo democrático, a assegurar controle, responsabilidade e publicidade de seus atos. Deve existir única nacionalidade israelo-palestina, propiciando-se aos nacionais a igualdade concernente a direitos, privilégios e benefícios provenientes da nacionalidade e a sujeição ao plexo de deveres e responsabilidades decursivos da nacionalidade. Incumbe ao Direito Legislado nacional disciplinar a aquisição, perda e reaquisição da nacionalidade (capítulo 1, seç. 3a.).

Inspirando-se na Constituição da Índia de 1950, impende à Carta Constitucional do Estado Israelo-Palestino agasalhar a igualdade de toda população inserida em seu território (art. 14), inclusive no tocante à liberdade de movimento (art. 15 (2)) e à proteção contra discriminações, mormente quanto à religião, gênero sexual e origem social, étnica, racial, domiciliar ou atinente à ascendência familiar (art. 15, c/c art. 16), sem prejuízo de medidas legislativas e administrativas voltadas a fomentar o 
desenvolvimento de segmentos desfavorecidos sob o ângulo educacional e socioeconômico (art. 15 (4)). Importante o ditame da isonomia englobar o estabelecimento de iguais oportunidades de ingresso seja ao serviço público (art. 16), seja ao mercado de trabalho (art. 41).

Demais disso, ainda em relação ao paradigma da Constituição indiana, releva a Constituição israelo-palestina insculpir os seguintes direitos fundamentais:

1) Liberdade religiosa extensiva a movimentos econômicos, financeiros, políticos e outras expressões sociais seculares associadas a práticas religiosas (art. 25 (2) (a));

2) Direito das denominações religiosas ao estabelecimento de instituições de fins religiosos e caritativos (art. 26 (a)), à autonomia para decidir acerca de questões religiosas interna corporis (art. 26 (b)), a ter, adquirir e administrar propriedade móvel e imóvel, de acordo com as prescrições legais (art. 26 (c) (d));

3). Direito de comunidades situadas no território nacional preservarem sua cultura (inclusive idioma) (art. 29 (2)) e gerirem seus educandários, sem discriminação estatal (art. 30 (2));

4) Condicionar as hipóteses legais de expropriações ao pagamento de indenização correspondente, no mínimo, ao preço de mercado (art. 31A, in fine).

Além dos direitos fundamentais, necessário atentar para estes deveres fundamentais (postos na Carta Magna da Índia e direcionados aos nacionais):

1) Promoção da harmonia e do espírito da irmandade comum a todo o povo, transcendendo diversidades religiosas, lingüísticas, regionais e locais, bem como renúncia a práticas contrárias à dignidade feminina;

2) Valorização e preservação da rica herança da plural cultura nacional;

3) Defesa do patrimônio público e repulsa à violência.

Na seara do Direito de Família e das Sucessões, as comunidades religiosas (muçulmana, judaica e cristã) e não-religiosas devem se nortear por legislação específica para cada uma delas. Exemplo disso, na Índia, a Lei de Dissolução dos Casamentos Muçulmanos (The Dissolution of Muslim Marriages Act, 1939 - Act no. 8 of 1939-) e a Lei do Casamento Hindu (The Hindu Marriage Act, 1955 - Act no. 25 of 1955-).

Pertinente também legislação específica para cada comunidade religiosa, acerca da educação e da filantropia exercitadas por instituições reli- 
giosas e legislação geral para preservação de espaços religiosos (templos, por exemplo) — v. g., na Índia, a Lei de Lugares de Culto Religioso (Places of Worship (Special Provisions) Act, 1991) — e proibição seja de uso de espaços religiosos para atividade política ou criminosa, seja de emprego de símbolos religiosos em campanha político-eleitoral - e.g., na Índia, a Lei de Representação do Povo (The Representation of the People Act, 1951)-.

Enfatize-se a importância de legislação que (1) regulamente o exercício igualitário da imigração e da aquisição de nacionalidade, (2) incentive a reconciliação nacional, (3) resguarde a comunidade judaica de medidas expropriatórias e (4) promova a distribuição de renda e a inclusão social de segmentos marginalizados, tendo os legisladores, neste terceiro aspecto, por parâmetro de reflexão, as políticas públicas e a jurisprudência dos Estados Unidos concernentes à ação afirmativa (na Suprema Corte dos EUA, por exemplo, University of California Regents V. Bakke, 438 U.S. 265 (1978), de 28 de junho de 1978) e a Lei de Capacitação Negra, da África do Sul (Broad-Based Black Economic Empowerment $A c t, 2003)$. Saliente-se que as prescrições encapsuladas na Convenção Internacional Anti-Apartheid de 1973 (Convenção Internacional de Supressão e Punição do Crime de Apartheid) merecem servir de analogia para a ordem constitucional da República israelo-palestina.

Há que se volver os olhos, com discernimento e ponderação, para o federalismo comunitário ${ }^{72}$ do Líbano, assente no Pacto Nacional (consuetudinário) de 1943 (al Mithaq al Watani), atualizado por pactuação formal, o Acordo de Ta'if de 1989, a compartilhar o exercício do poder temporal entre os diversos segmentos cristãos e muçulmanos da sociedade libanesa, de modo que hoje existe número paritário de assentos no Parlamento daquele País para cristãos e muçulmanos e se encontra predefinido o papel político-institucional de cada agrupamento religioso das comunidades muçulmana e cristã, inclusive os cargos políticos que podem desempenhar os representantes de cada segmento muçulmano e cristão. O modelo libanês deve ser emulado de maneira cautelosa, prudência com o propósito de se evitar que, em vez de robustecer o Estado israelo-palestino, empecilhe, ao longo das décadas, a reconciliação nacio-

72 Mallat, Chibli, Communitarian Federalism: addressing the Middle East constitucional impasse. Disponível em: http://www.obreal.unibo.it/File.aspx?IdFile= 283. Acesso em 24 de julio de 2006. 
nal, por meio de divisões político-institucionais que podem, a exemplo da experiência do Líbano, se mostrar defasadas e servir de ensejo para disputas sectárias. ${ }^{73}$ Quanto ao paradigma libanês, revela-se fundamental atentar para a preocupação política de que o Parlamento espelhe todos os segmentos religiosos libaneses e que, no cômputo final de cadeiras naquela Casa Legislativa, as comunidades muçulmanas não prevaleçam sobre as cristãs e vice-versa.

\section{A advertência de Richard W. Murphy}

Richard W. Murphy, ex-Embaixador dos Estados Unidos na Síria e na Arábia Saudita, membro do Conselho de Relações Exteriores (Council on Foreign Relations - CFR-), prestigiosa instituição estadunidense de estudos de Política Internacional, afiança que quanto mais tempo os Estados Unidos perdem em busca do isolamento a organizações terroristas (a exemplo, nos anos 1980, da Organização para a Libertação da Palestina, e, na atualidade, do Hamas), mais difícil se torna lidar com (e conter) o fundamentalismo árabe e muçulmano, que assim se fortalece. Síria e Irã, Hamas e Hezbollah, ${ }^{74}$ não serão neutralizados mediante boicote ostensivo dos Estados Unidos e retaliações militares de Israel.

Depreende-se, portanto, que a questão imediata do muro de Israel no Território Palestino Ocupado e mediata do conflito israelo-palestino demanda tratativa diplomática eficaz dos Governos de Israel e dos EUA com os Governos da Síria ${ }^{75}$ e do Irã, bem assim com o Hamas e o Hezbollah, organizações que não desaparecem por meio de intensos ataques armados e sanções econômicas. Ao contrário, as ofensivas militares de Israel e diplomáticas dos Estados Unidos são mecanismos hábeis em consolidar a legitimidade de tais movimentos político-terroristas e propiciar a eles maior admiração em setores moderados da comunidade árabe e islâmica internacional, que passam a enxergá-los como abnegadas for-

73 St John, Ronald Bruce, Lebanon No Model for Iraq. Disponível em: http://www.fpif.org/fpiftxt/1087. Acesso em: 24 de julio de 2006.

74 Entrevista de Richard W. Murphy ao jornalista Jonathan Mann, âncora do programa de televisão "Insight", da CNN International, em 28 de julio de 2006.

75 Gwertzman, Bernard, Murphy: concerned that Israeli attack 'could be the first of a series'. Disponível em: http://www.cfr.org/publication/6423/murphy.html. Acesso em: 28 de julio de 2006. 
ças de resistência ao imperalismo estadunidense no Oriente Médio e ao colonialismo judaico em territórios árabes. ${ }^{76}$

Murphy recomenda aos Estados Unidos e às demais nações do Ocidente firmarem canais de diálogo com setores do movimento político islâmico (a exemplo da Irmandade Islâmica, no Egito) que possuem viés religioso mas não acalentam, nem propagam o ideal de se encampar guerra santa contra o Ocidente. Assim seria possível evitar choques de civilização entre o Islã e sociedades ocidentais, o que, a nosso sentir, também arrefeceria, por conseqüência, a tensão entre Israel e o mundo árabe e muçulmano, contribuindo, dessa forma, para a desconstrução do muro israelense no Território Palestino Ocupado.

\section{CONCLUSÃO}

1. Embora louvável o pungente esforço da Corte Internacional de Justiça de esclarecer o rol de violações do Estado de Israel ao Direito Internacional, ao construir e manter muro defensivo situado no Território Palestino Ocupado, sua opinião consultiva de 9 de julho de 2004 merece ser reavaliada, mediante minuciosa e dialética análise, baseada nos critérios da necessidade e proporcionalidade, de cada segmento da barreira de segurança do Estado judeu, sopesando os efeitos benéficos à segurança da sociedade israelense, em face do terrorismo islâmico oriundo do Território Palestino Ocupado, com os efeitos maléficos à dignidade das comunidades palestinas localizadas em tal região.

2. Enquanto não houver acordo de paz permanente entre Israel e as facções político-paramilitares palestinas, não existirá medida estatal de defesa antiterrorista tão eficaz e, ao mesmo tempo, menos ofensiva que o muro israelense sito no Território Palestino Ocupado.

3. Solução duradoura para a permitir a desconstrução do muro de Israel envolve processo gradativo de transição, calçada em acordo de paz eficaz, que preveja a fundação do Estado da Palestina nos territórios já desocupados, na posterior assunção do controle do Estado palestino sobre o atual Território Palestino Ocupado e na coexistência pacífica entre

76 Murphy, Richard W. y Eastwood, Basil, We must talk to Hamas. Disponível em: http://www.aljazeerah.info/Opinon\%20editorials/2006\%20Opinion\%20Editorials/May/2 0\%20o/We\%20Must\%20Talk\%20to\%20Hamas\%20By\%20Richard\%20W.\%20Murphy\% 20 and\%20Basil\%20Eastwood.htm. Acesso em: 28 de julio de 2006. 
os Estados de Israel e da Palestina, sucedida pela fusão dos Estados judeu e palestino em Estado binacional, federal, democrático e laico, respeitada a autonomia religiosa e civil das comunidades judaica, muçulmana e cristã.

\section{BIBLIOGRAFIA}

ABU-ODEH, Lama, "The case for binationalism: why one state - liberal and constitutionalist - may be the key to peace in the Middle East", Boston Review, Boston, diciembre de 2001-enero de 2002. Disponível em: http://bostonreview.net/ndf.html\#Binationalism. Acesso em: 18 de julio de 2006.

"Assentamentos judeus crescem na Cisjordânia", Folha de S. Paulo, São Paulo, 27 de agosto de 2005. Disponível em: http://www.uol.com.br/ fsp. Acesso em: 27 de agosto de 2005.

BARGOUTI, Omar, The fundamental Obstacle to a one State Solution. Disponível em: http://fromoccupiedpalestine.org/. Acesso em: 18 de julio de 2006.

DALAL, Marwan, "Another Brick in the Wall: Between Israeli Law and the ICJ's Advisory Opinion", Adalah's Newsletter, Shafa'amr, vol. 15, julio de 2005. Disponível em: http://www.adalah.org. Acesso em: 27 de agosto de 2005.

FEINSTEIN, Barry A. y WeINER, Justus Reid, "Israel's security barrier: an international comparative analysis and legal evaluation", The George Washington International Law Review, Washington D.C., vol. 37, núm. 2, pp. 309-467, mayo-agosto de 2005. Disponível em: http:// proquest.umi.com $/$ pqdlink? did $=845160441 \&$ sid $=1 \& F m t=4 \&$ clientI $d=65353 \& R Q T=309 \& V$ Name $=P Q D$. Acesso em: 27 de agosto de 2005.

GWERTZMAN, Bernard, Murphy: concerned that Israeli attack 'could be the first of a series'. Disponível em: http://www.cfr.org/publication/6423/murphy.html. Acesso em: 28 de julio de 2006.

HIRSCHBERG, Peter, One state awakening. Ha'aretz, Tel Aviv, diciembre de 2003. Disponível em: http://www.zmag.org/content/showarticle. cfm? ItemID=4693. Acesso em: 17 de julio de 2006.

Israel, Basic Law: Jerusalem, Capital of Israel, 1980. Disponível em: http://www.knesset.gov.il. Acesso em: 24 de agosto de 2005. 
, Israel Security Fence-Ministry of Defense. Disponível em: http://www.seamzone.mod.gov.il. Acesso em: 24 de agosto de 2005. - Golan Heights Law. Disponível em: http://www.jewishvirtual library.org/jsource/History/Golan_Heights_Law.html. Acesso em: 19 de julio de 2006.

- The Law of Return 5710, 1950. Disponível em: http://www. knesset.gov.il. Acesso em: 18 de julio de 2006.

- Ministry of Foreing Relations. Saving Lives: Israel's anti-terrorist fence. Disponível em: http://www.mfa.gov.il. Acesso em: 24 de agosto de 2005.

— Ministry of Defence, Israel's response to the ICJ advisory opinion on the Security Fence. Disponível em: http://www.securityfence. mod.gov.il. Acesso em: 26 de agosto de 2005.

—- Security Fence's Effectiveness. Disponível em: http://www. securityfence.mod.gov.il. Acesso em: 26 de agosto de 2005.

- Supreme Court of Israel. H. C. J. 2056/04. Beit Sourik Village Council vs. The Government of Israel and the Commander of the IDF Forces in the West Bank. Disponível em: http://www.court. gov.il. Acesso em: 22 de marzo de 2005.

- H. C. J. 7957/04. Zaharan Yunis Muhammad Mara'abe, Morad Ahmed Muhammad Ahmed, Muhammad Jamil Mas'ud Shuahani, Adnan Abd el Rahman Daud Udah, Abd el Rahim Ismail Daud Udah, Bassem Salah Abd el Rahman Udah and the Association for Civil Rights in Israel v. the Prime Minister of Israel, the Minister of Defense, the Commander of IDF Forces in the Judea and Samaria Area, the Separation Fence Authority and the Alfei Menashe Local Council. Disponível em: http://www.court. gov.il. Acesso em: 9 de julio de 2005.

JuDT, Tony Israel, "The Alternative", The New York Review of Books, Nueva York, vol. 50, núm 16, 23 de octubre de 2003. Disponível em: http://www.nybooks.com/articles/16671. Acesso em: 17 de julio de 2006.

Koroma, Abdul G., Separate Opinion of Judge Koroma. The Hague, 9 de julio de 2004. Disponível em: http://www.icj-cij.org. Acesso em: 22 de agosto de 2005.

KRETZMER, David, "ICJ advisory opinion on construction of a wall in the occupied Palestinian Territory: the advisory opinion: the light treatment of international humanitarian law", American Journal of 
International Law, Washington D.C., vol. 99, núm. 1, enero de 2005, pp. 88-102.

LAZARE, Daniel, "The one-State solution", The Nation, Nueva York, 3 noviembre de 2003. Disponível em: http://www.thenation.com. Acesso em: 28 de agosto de 2005.

Mallat, Chibli, Communitarian Federalism: addressing the Middle East constitucional impasse. Disponível em:http://www.obreal. unibo.it/File.aspx?IdFile=283. Acesso em: 24 de julio de 2006.

MoosA, Ebrahim, "No easy solution: a response to "The case of binationalism'", Boston Review, Boston, diciembre de 2001-enero de 2002. Disponível em: http://bostonreview.net/ndf.html\#Binationalism. Acesso em: 18 de julio de 2006.

MurPHY, Richard W. y EASTwOOD, Basil, We must talk to Hamas. Disponível em: http://www.aljazeerah.info/Opinion\%20editorials/ 2006\%20Opinion\%20Editorials/May/20\%20o/We\%20Must\%20Talk $\% 20$ to\%20Hamas\%20By\%20Richard\%20W.\%20Murphy\%20and\%2 OBasil\%20Eastwood.htm. Acesso em: 28 de julio de 2006.

Organização das Nações Unidas, Carta das Nações Unidas, 1945. Disponível em: http://www.dhnet.org.br. Acesso em: 24 de agosto de 2005.

, International Court of Justice. Advisory Opinion, Legal consequences of the construction of a wall in the Occupied Palestinian Territory, The Hague, 9 de julio de 2004. Disponível em: http:// www.icj-cij.org. Acesso em: 22 de agosto de 2005.

_ Judgment. Case concerning military and paramilitary activities in and against Nicaragua (Nicaragua vs. United States of America), The Hague, 27 de junio de 1986. Disponível em: http://www. icj-cij.org. Acesso em: 22 de agosto de 2005.

OwADA, Hisashi, Separate Opinion of Judge Owada, The Hague, 9 de julio de 2004. Disponível em: http://www.icj-cij.org. Acesso em: 22 de agosto de 2005.

Palestinian Centre for Human Rights, Securing the Wall from International Law: an initial response to the Israeli State Attorney, Gaza City: PCHR, 2005 (PCHR Position Paper). Disponível em: http:// www.pchrgaza.org. Acesso em: 28 de agosto de 2005.

SAID, Edward, "The one-State solution", The New York Times, Nueva York, 10 de enero de 1999. Disponível em: http://www.members.tripod.com/ TheHOPE/said.htm. Acesso em: 28 de agosto de 2005. 
ST. JoHN, Ronald Bruce, Lebanon No Model for Iraq. Disponível em: http://www.fpif.org/fpiftxt/1087. Acesso em: 24 de julio de 2006.

STEINBERG, Gerald M., "The UN, the ICJ and the separation barrier: war by other means", Israel Law Review, Jerusalem, vol. 38, núm 1-2, 2005, pp. 331-347.

TAMARI, Salim, "The binationalist lure: a response to "The case of binationalism"", Boston Review, Boston, diciembre de 2001-enero de 2002. Disponível em: http://bostonreview.net/ndf.html\#Binational ism. Acesso em: 18 de julio de 2006.

TILlEY, Virginia, "The one-State solution", London Review of Book, Londres, vol. 25, núm. 21, 6 de noviembre de 2003. Disponível em: http://www.lrb.co.uk. Acesso em: 28 de agosto de 2005. 